\title{
Relationships between the Sakarya Zone and the Ankara-Erzincan suture (central-northern Turkey): geological and petrographic data from the Ankara-Çankiri, Çorum and Amasya areas
}

\author{
ENRICO PANDELI* $+\dagger$, FRANCO MARCO ELTER§, FATMA TOKSOY-KÖKSAL $₫$, \\ GIANFRANCO PRINCIPI*, ANDREA ORLANDO \\ RICCARDO GIUSTI* \& LETIZIA ORTI* \\ * Department of Earth Sciences, University of Florence, Florence, Italy \\ †CNR-Institute of Geosciences and Earth Resources, U.O.S. of Florence, Florence, Italy \\ $\S$ DISTAV, University of Genoa, Genoa, Italy \\ |Department of Geological Engineering, Middle East Technical University, Ankara, Turkey
}

(Received 27 September 2016; accepted 23 May 2017; first published online 29 August 2017)

\begin{abstract}
The study was performed in central-northern Anatolia (from Ankara to Amasya) to investigate the relationships of the Sakarya Zone units and the Izmir-Ankara-Erzincan suture (IAES) melange. It reveals that all the Sakarya Zone units are metamorphic and three main tectonostratigraphic units have been distinguished for the first time: the BAA (metasiliciclastic rocks capped by metacarbonates and varicoloured phyllite), the BKC (poly-metamorphic garnet-bearing micaschist and metabasite with a well-preserved relict HP-LT amphibole in a low-amphibolitic to greenschistfacies framework) and the AMC (meta-arkose passing vertically to carbonate-phyllitic alternations and, then, to a thick succession of prevailing acidic to intermediate-basic metavolcanites and volcanicrich metasediments). The BAA and AMC, whose metamorphic frameworks are of Cimmerian age, underlie the Mesozoic carbonate cover sequences (e.g. $\mathrm{t}_{2-3}, \mathrm{j}_{3}-\mathrm{k}_{1}$ ) that often show tectonic detachments and slicing. The piling up of the BAA above the HP-LT BKC can be correlated to the tectonic superposition of two similar units (i.e. the Cimmerian Çangaldağ Complex and the Alpine MiddleUpper Cretaceous Domuzdağ Complex, respectively) defined by previous authors in other sectors of the Central Pontides front. The ophiolitic melange generally underlies the Sakarya Zone, but locally (e.g. SE of Amasya) tectonically rests above the latter, probably owing to back-thrusting that occurred during the Tertiary syn-collisional shortenings and the later strike-slip tectonics. We hypothesize that, also in these areas, the Sakarya Zone-IAES consists of a complex tectonic stack of different units, belonging to different palaeogeographic domains and orogenic events (Cimmerian versus Alpine orogenies), but originated within a single long-lived (since Late Triassic to Paleocene/Eocene times), prograding subduction-accretion system in front of the Laurasian continent.
\end{abstract}

Keywords: central-northern Turkey, Sakarya Zone, ophiolitic melange, stratigraphy, petrographymineral chemistry, structural geology

\section{Introduction}

The Anatolia Peninsula is one of the best places in the world to study the evolution of oceanic Tethyan basins and the following birth of orogenic chains (Robertson et al. 2004; Okay, 2008; Göncüoğlu, 2010; Okay \& Whitney, 2010; Aygül et al. 2016). The disappearance of oceanic basins is testified to by suture zones, among which the Izmir-Ankara-Erzincan suture zone (IAESZ) or North Anatolian Ophiolite Belt (NAOB) is well known (Fig. 1) (Şengör \& Yilmaz, 1981; Şengör, 1984; Göncüoğlu, 2010). The sutures are mostly made up of ophiolitic units and melanges that locally show evidence of regional metamorphism up to the medium grade that occurred during the intra-oceanic shortening (e.g. the Cretaceous greenschist- to amphibolitefacies rocks of the 'metamorphic soles' cut by gabbro and diabase dykes: Çelik, Delaloyle \& Feraud, 2006;

$\dagger$ †uthor for correspondence: enrico.pandeli@unifi.it
Parlak, Yilmaz \& Boztuğ, 2006). Moreover, witnesses of high-pressure - low-temperature (HP-LT) metamorphism are locally preserved, especially in some of the units belonging to the palaeocontinental margins (see Section 5 below) (Okay, 2008; Aygül et al. 2016 and references therein), which are correlated to the blueschist-facies Cycladic Island units of the Aegean Sea (Oberhänsli et al. 1998; Régnier et al. 2003; Ring et al. 2007). In this context, the authors studied the relationships between the continental units in the frontal part of the composite terrane of the Sakarya Zone (Southern Pontide Domain) and the ophiolitic melange in the central sector of the IAESZ in the areas between Ankara and Amasya, performing lithostratigraphic and structural observations at the meso-scale along different transects (locations in Fig. 2a, b, c, d), and analysing at least 150 samples for petrographic, microstructural and mineral chemistry characterizations. The first results of the study (based on 55 selected samples) are shown in this paper, which reveals a more complex 


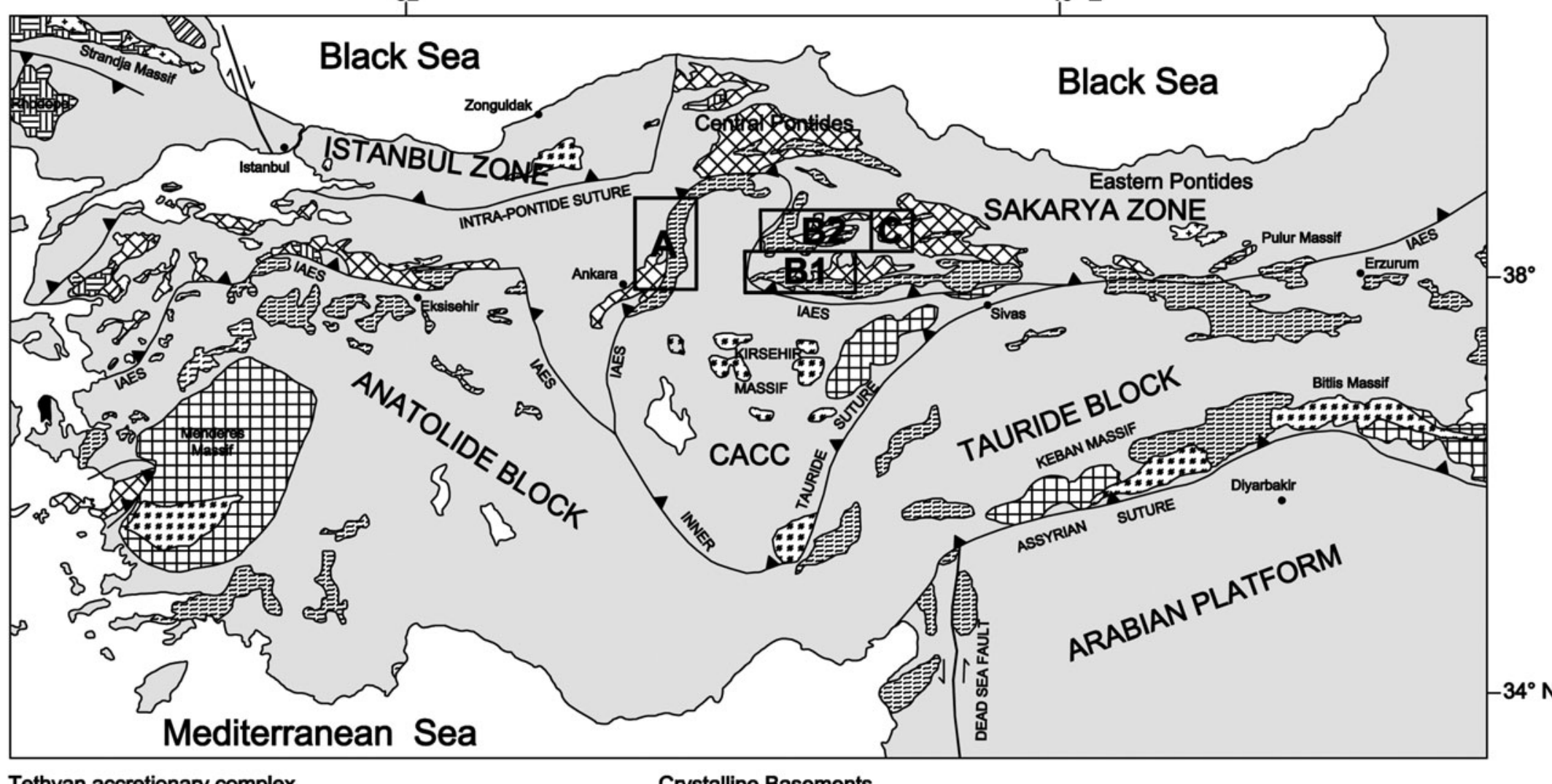

Tethyan accretionary complex

Ophiolite Melanges (Late Cretaceous-Tertiary)

VIIIA Strandja Complex (Triassic-Early Jurassic)

XX Karakaya-Kure Complex (Late Triassic-Early Jurassic)
Crystalline Basements

Post-Variscan Complexes

++++ Pre-Jurassic granites

睡盂 Variscan Complexes
IAES: Izmir-Ankar-Erzinlan Suture

CACC: Central Anatolian Crystalline Complex

\section{1:*:: Pan African Complexes}

Figure 1. Tectonic sketch of Turkey and surrounding regions showing the major sutures (Intra-Pontide Suture, Izmir-Ankara-Erzincan Suture (IAES), Inner Tauride Suture, Assyrian Suture) and continental blocks (Istanbul Zone, Sakarya Zone, Central Anatolia Crystalline Complex (CACC) or Kirsehir block, Anatolide-Tauride block, Arabian Platform) with the location of the study areas (see A, B1, B2 and C squared areas); the Tethyan accretionary complexes (including ophiolitic melanges) and the main crystalline massifs are also distinguished (modified from Okay et al. 2006). 


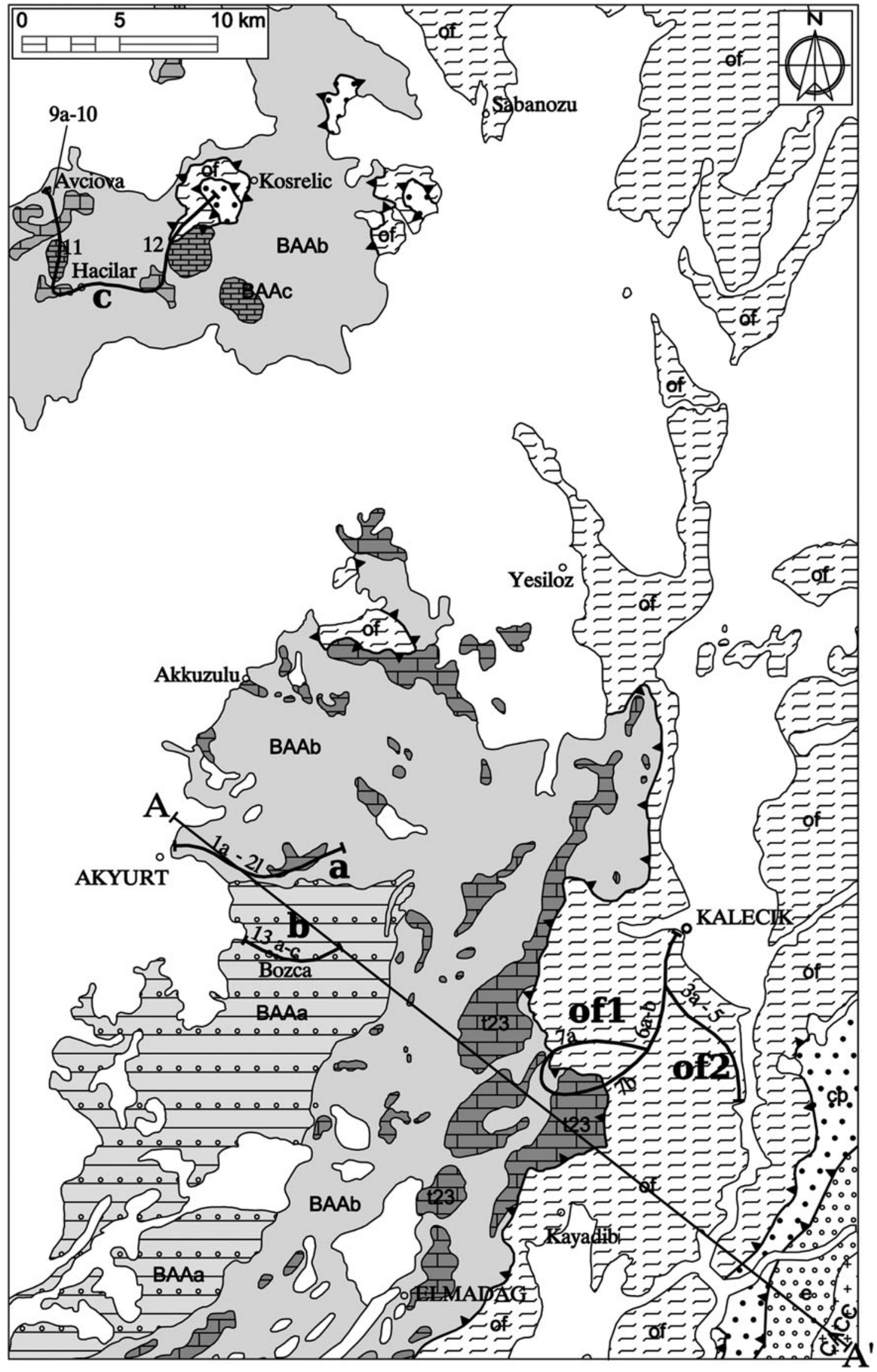

Figure 2. (a) Geological sketch map of the Akyurt-Kalecik and Avciova-Şabanözü areas (A in Fig. 1). 


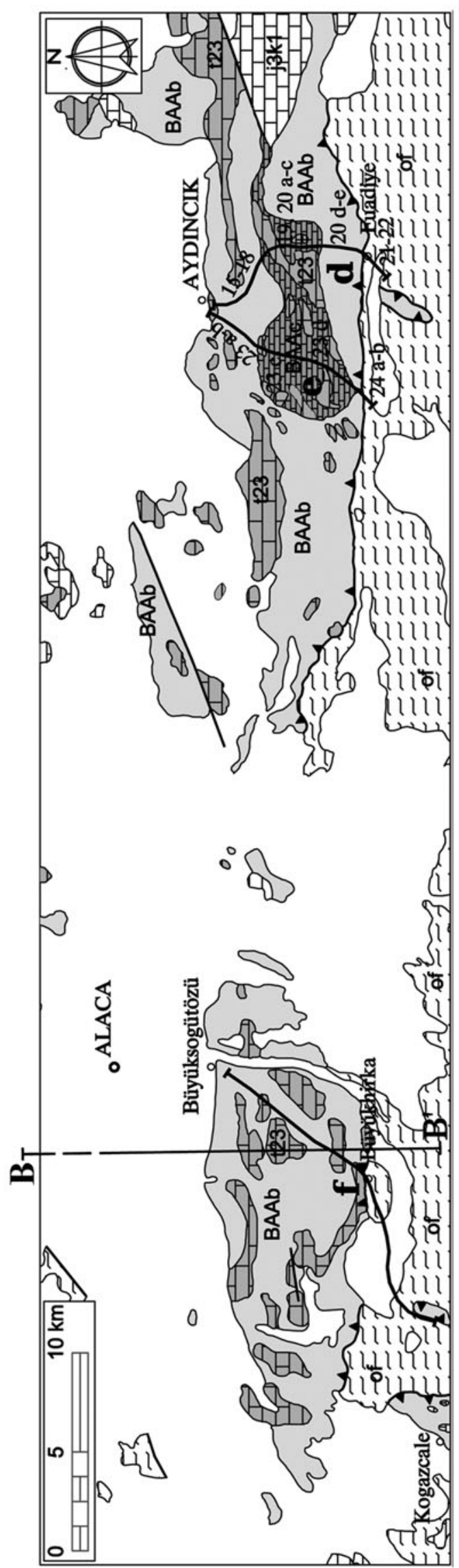

Figure 2. (Continued) (b) Geological sketch map of the AlacaAydincik area (B1 in Fig. 1). stratigraphic and structural framework with respect to the previous geological knowledge about this part of the Sakarya Zone front.

\section{Geological framework of Turkey}

Turkey is a key area for reconstructing a coherent geodynamic model for the Eastern Mediterranean area. In particular, the geological framework of the Eastern Mediterranean is the result of a series of geodynamic events that followed the closure of the Palaeozoic earliest Triassic Palaeotethys during the Late Triassic - earliest Jurassic/Early Cretaceous Cimmerian Orogeny (Göncüoğlu et al. 2004; Catlos, Huber \& Shin, 2013; Okay \& Nikishin, 2015; Aygül et al. 2016), developing intra-oceanic arc, inter-arc and back-arc areas (e.g. Rojay, 1995; Genç \& Tüysüz, 2010). These events also produced the ?Permian-Triassic rifting and ocean spreading of the Neotethys in the equatorial part of Pangaea (Şengör, 1984), whose closure occurred in the Late Triassic to Early Cretaceous/Paleocene time interval (Okay \& Göncüoğlu, 2004; Catlos, Huber $\&$ Shin, 2013). The spreading of the Neotethys has been related to a single oceanic area (Şengör, 1984; Stampfli, Marcoux \& Baud, 1991), but the presence of intervening marginal basins has also been speculated (e.g. Catlos, Huber \& Shin, 2013). So, the resulting Neotethys Ocean was subdivided into various branches which separated a series of continental blocks or composite terranes (i.e. Pontides, Anatolides-Taurides, Arabian Platform) between Gondwana and Laurasia. In this framework, the Anatolian Peninsula (i.e. Anatolian Plate) is geologically segmented into two main zones, from $\mathrm{N}$ to $\mathrm{S}$, the Pontides (Strandja, İstanbul and Sakarya terranes or complexes) and Anatolides (Menderes Massif, Central Anatolian Crystalline Complex $=$ CACC or Kurşehir Massif) - Taurides (Tavşanlı and Afyon zones, Kütahya-Bolkardağ Belt) (Fig. 1) (Okay, 2008; Göncüoğlu, 2010; Aygül et al. 2016). These are separated by the main evident ophiolitic suture, i.e. the IAESZ, due to the northward subduction of the northern Neotethys branch; in contrast, the Assyrian suture or Southern Tauride suture zone (TSZ) divides the Taurides from the Arabian Platform, due to the northward subduction of the southern Neotethys branch and southward obduction of ophiolitic units onto the Arabian Platform itself (Şengör \& Yilmaz, 1981; Şengör, 1984; Göncüoğlu, Dirik \& Kozlu, 1997; Okay, Harris \& Kelley, 1998; Okay et al. 2001; Robertson et al. 2004; Okay, 2008; Göncüoğlu, 2010; Robertson et al. 2014; Aygül et al. 2016). The Inner Tauride suture, between the CACC and the Tauride block, and the Intra-Pontide suture, between the Strandja + İstanbul terranes and the Sakarya Zone, have also been defined (see Figure 1, e.g. Şengör \& Yilmaz, 1981; Okay, 2008; Göncüoğlu, 2010; Göncüoğlu et al. 2014; Marroni et al. 2014). According to some authors (Okay \& Tüysüz, 1999; Göncüoğlu et al. 2004; Göncüoğlu, 2010), this latter suture is generally related to the Late Triassic 


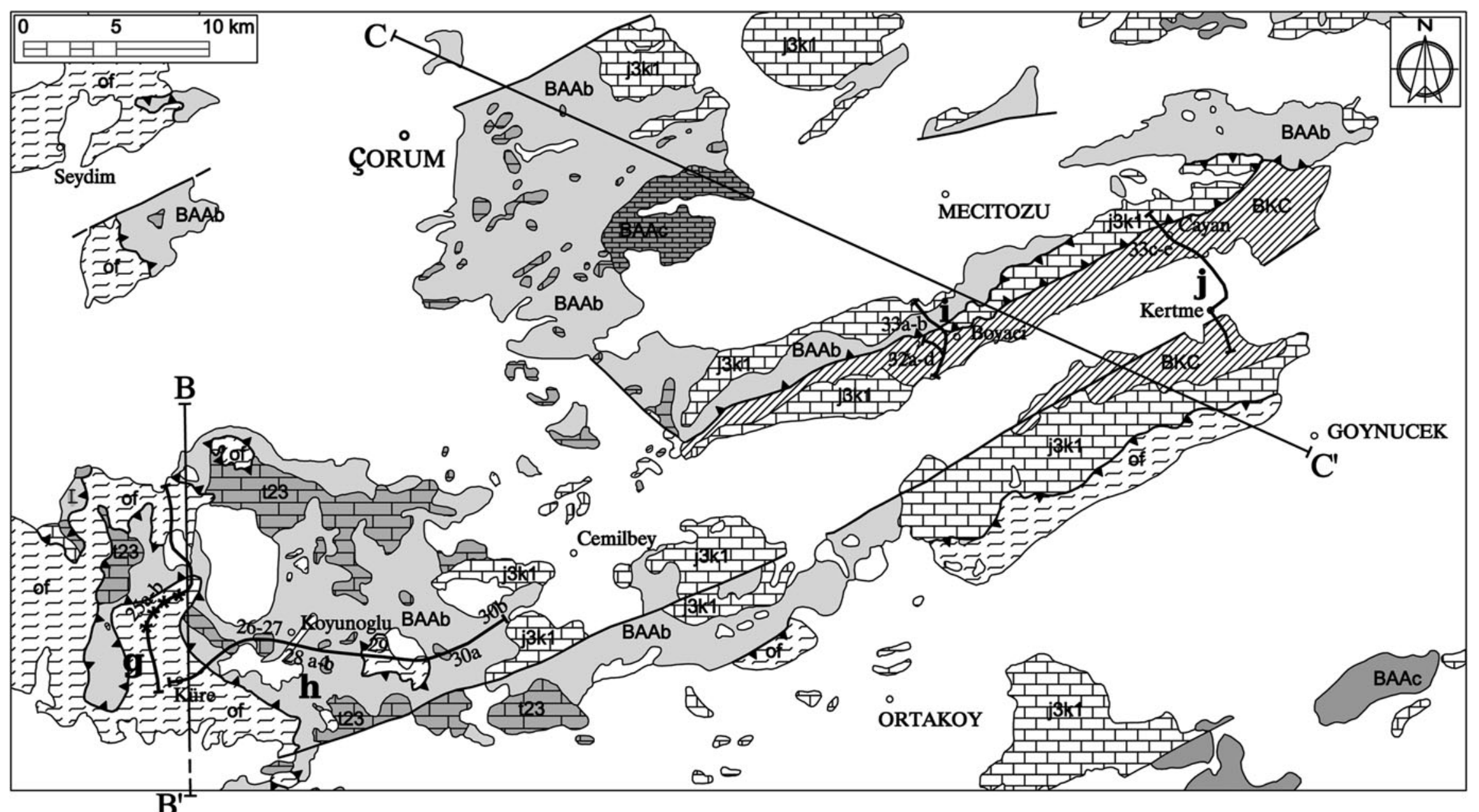

Figure 2. (Continued) (c) Geological sketch map of the areas S and SE of Çorum (B2 in Fig. 1). 


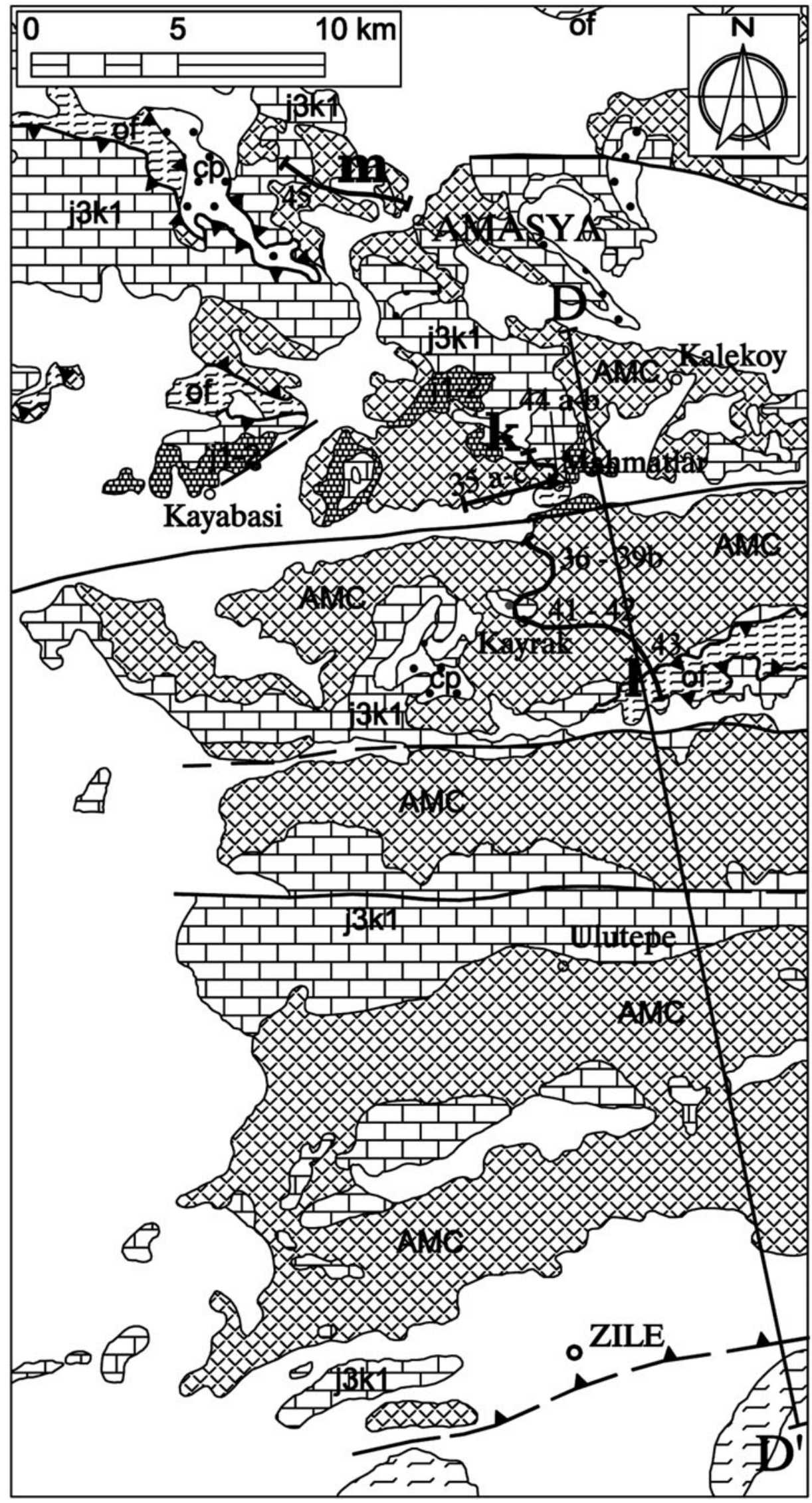

Figure 2. (Continued) (d) Geological sketch map of the Amasya area (C in Fig. 1) with locations of the studied transects and of the selected samples (modified from MTA, 2002). 


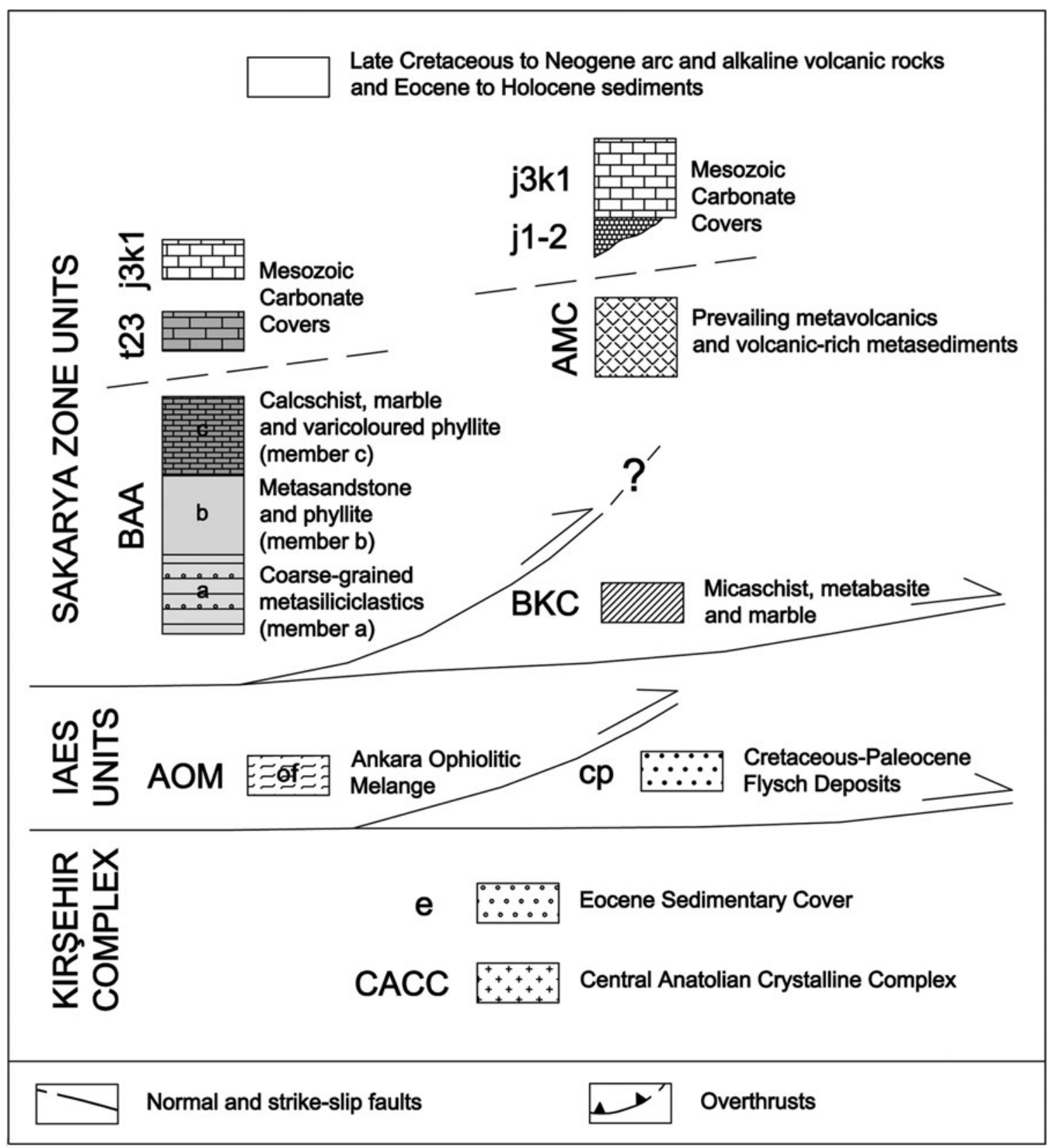

Figure 2. (Continued) (e) Legend to geological sketch maps and cross-sections.

accretion of the Sakarya terrane pro parte (Variscan Massifs microplate and Cimmerian Karakaya Complex) and of the Palaeotethys oceanic area (e.g. Çangaldağ Complex, Nilüfer unit) to the Eurasian margin. This event is testified to by the Late Triassic metamorphism in the blueschist-eclogite and greenschist facies (i.e. 205-203 Ma in the Karakaya Complex; 215-204 Ma in the Nilüfer unit; Okay, Monod \& Monié, 2002).

The oceanic sutures are characterized by the presence of typical or unusual mid-ocean ridge (MORB-), ocean island basalt (OIB-) and island arc tholeiite (IAT)-type (supra-subduction zone) ophiolitic successions, including serpentinized mantle and gabbros covered by volcano-sedimentary covers, and of peculiar thick ophiolitic melanges (Göncüoğlu, 2010; Bortolotti et al. 2013; Bortolotti, Chiari \& Pandeli,
2016 and references therein). These latter are not only made up of serpentinized peridotite components, but also include clasts up to megaolistoliths of the volcano-sedimentary cover sequences (e.g. basalts, cherts and limestones) and of minor continental carbonate rocks. Part of the Neotethys oceanic and continental units suffered HP-LT metamorphism during the closure of the ocean during Cretaceous (e.g. the Sakarya Zone in Okay et al. 2006; Aygül et al. 2015, 2016) to Eocene times (western and central Anatolides, e.g. the Menderes Massif in Oberhänsli et al. 1997; Rimmelé et al. 2003; Oberhänsli, Candan \& Wilke, 2010; Pourteau, Candan \& Oberhänsli, 2010; Okay, 2011; Pourteau et al. 2015). According to some authors (Okay et al. 2006 and references therein), the Late Cretaceous-Tertiary? subduction-accretion processes onto the Sakarya margin also included the 

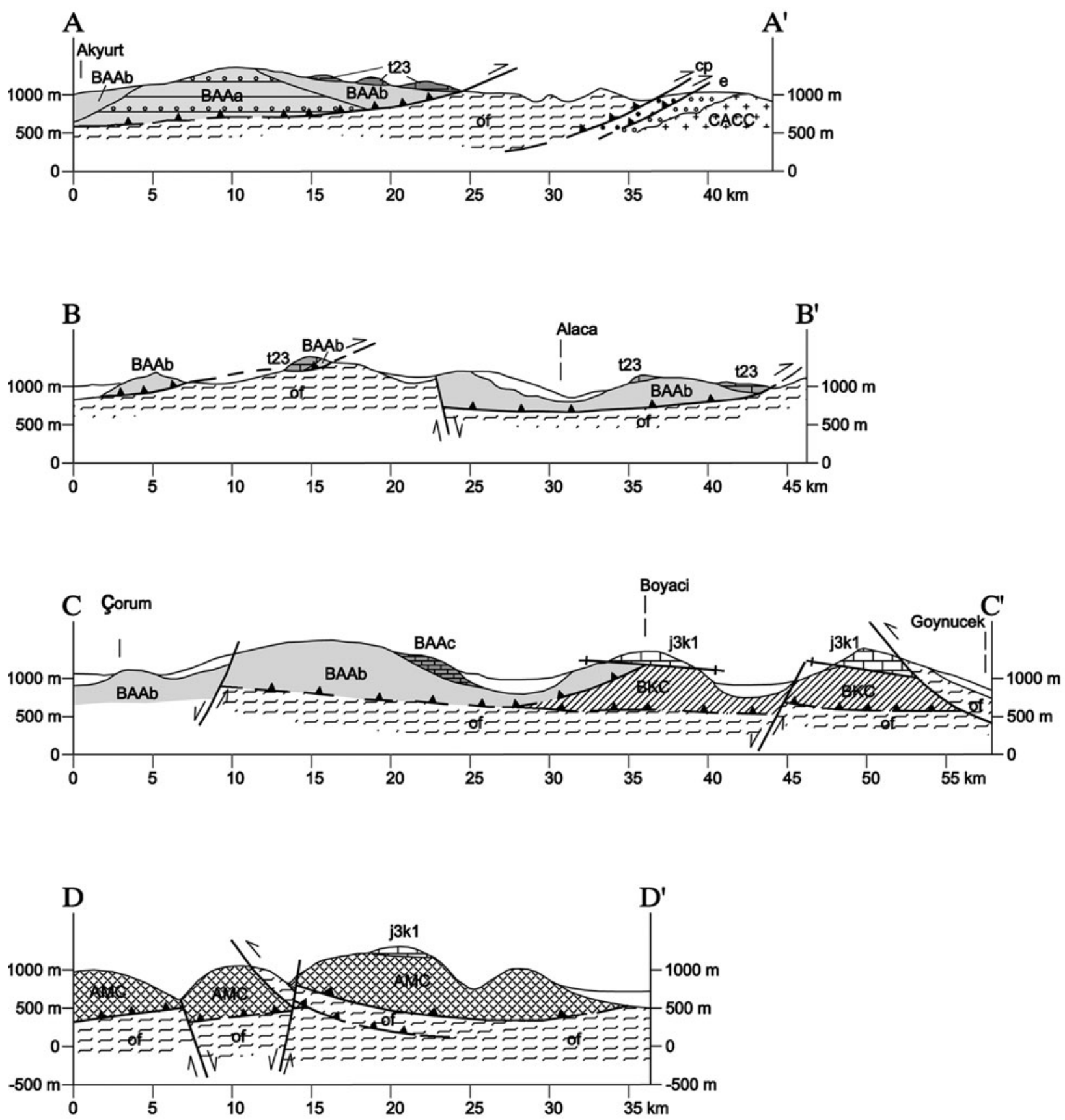

Figure 2. (Continued) (f) Geological cross-sections (locations shown in parts a-d).

welding of microcontinents (e.g. the Kargi microcontinent). During the Tertiary collisional events, the Turkey nappe stack, which is generally characterized by southern vergences, reached the present geological setting and some back-thrusting also locally occurred (Okay, 2008; Göncüoğlu, 2010; Robertson et al. 2014). At the same time, strong magmatic activities took place producing intrusive bodies and volcanic products, generally of calc-alkaline affinity (Göncüoğlu, 2010 and references therein). Finally, extensional tectonics occurred in Neogene time through low- and high-angle normal faulting producing the 'core complex'-like exhumation of the deep crystalline units (e.g. Menderes Massif) and the development of sedimentary basins (e.g. the continental basins of
Miocene age). Moreover, left-lateral, strike-slip tectonics characterized by transpressional faulting (e.g. the still active well-known North Anatolian Fault) was also originated by the south and southwest escaping movement of the Turkish and Aegean plates with respect to the northward-directed movement of the Arabic plate indenter and/or by the pull effect of the Hellenic subduction (Şengör et al. 2005; Okay, 2008 and references therein; Göncüoğlu, 2010).

\section{The Sakarya Zone front between the Ankara and Amasya areas}

This study was performed in selected areas of centralnorthern Anatolia, to the NE of Ankara (area A in 


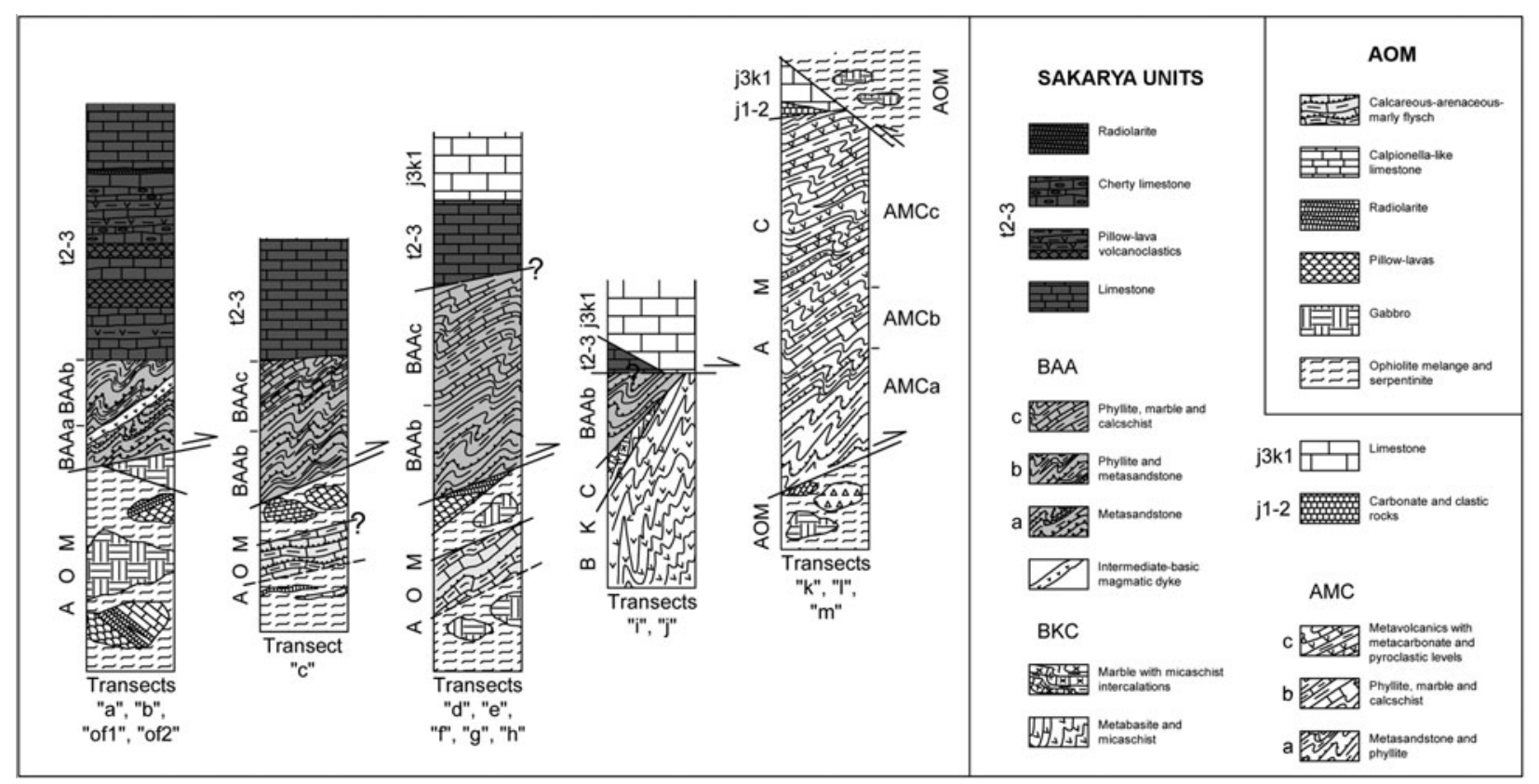

Figure 3. Simplified tectonic-stratigraphic columns: Akyurt-Kalecik-Bozca (transects 'a' and 'b', 'of1' and 'of2'); Avciova-Kosrelic (transect 'c'); Aydincik-Fuadiye (transects 'd' and 'e'), Büyüksogütözü-Kogazcale (transect 'f'), S of Çorum (transect 'g' along the Çorum-Alaca road, transect ' $h$ ' along the Küre-Cemilbey road); SE of Çorum (transect 'i' at Boyacı village, transect ' $j$ ' at KertmeÇayan villages); Amasya (transects ' $k$ ', ' 1 ' and 'm').

Fig. 1; Akyurt - transect 'a', Bozca village - transect 'b', Kalecik - transect 'of1' and 'of2' in Fig. 2a), SW of Çankırı (area A in Fig. 1; Avcıva-Kösrelik villages - transect ' $c$ ' in Fig. 2a), SSE and S of Alaca (area B1 in Fig. 1; Aydincik-Fuadiye villages - transects 'd' and 'e', Büyüksogütözü-Kogazcale villages - transect ' $\mathrm{f}$ ' in Fig. 2b), S and SE of Çorum (area B2 in Fig. 1; road Çorum-Alaca - transect ' $g$ ', Küre-Cemilbey villages - transect ' $h$ ', Boyac1 village - transect 'i', Kertme-Çayan villages - transect ' $j$ ' in Fig. 2c), and the northwestern part of the Tokat Massif (area $\mathrm{C}$ in Fig. 1; Mahmatlar village - transect ' $k$ ', Kayrak village - transect ' 'l', Amasya fortress road - transect ' $m$ ' in Fig. 2d). In these areas, the external Sakarya Zone units crop out and overthrust the IAESZ made up of the Ankara Ophiolitic Melange (AOM). More to the south of the studied localities, the latter tectonically overlies the CACC of the Kırşehir Massif units (Şengör \& Yilmaz, 1981; Göncüoğlu, Dirik \& Kozlu, 1997; Göncüoğlu, 2010) (see Figs 1, 2a).

In particular, we analysed the oceanic AOM and the lower part of the continental successions of the Sakarya Zone. According to the 1:500000 scale geological map of Turkey of the Turkish Geological Research Department of Mineral Research and Exploration General Directorate (MTA, 2002), these latter consist of two main units including PalaeozoicTriassic successions that lie below the Mesozoic carbonate platform cover sequences. In particular, the Sakarya Zone units are mapped in MTA (2002) as the sedimentary Permian-Triassic 'pt', composed of clastic and carbonate rocks, and the metamorphic Upper Palaeozoic-Triassic 'ş', composed of schist, phyllite, marble and metabasic rocks.

\section{Results}

\section{4.a. Lithostratigraphy and petrographic data}

The lithological and the main petrographic features of the studied transects in the AOM and in the Sakarya Zone units are described below. Simplified tectonostratigraphic schemes of the studied successions from different areas are given in Figure 3.

\section{4.a.1. AOM ('k2s', ' $k 2 \mu$ ', ' $\omega \delta$ ', 'of' and ' $k 2$ ' in MTA, 2002)}

This unit, particularly well exposed in the Kizilirmak River Valley (Fig. 4), consists of different elements of the Mesozoic oceanic units. In the composite transect 'of' ('of1' and 'of2' in Fig. 2a) to the south of Kalecik, the AOM is an overall grey to green tectonic melange showing a 'block-in-matrix'-type fabric (' $\mathrm{k} 2 \mathrm{~s}$ ' in MTA, 2002) and it is made up of heterometric breccia with serpentinite and serpentinized peridotite clasts, up to boulders in size (Fig. 5a) embedded in a medium- to fine-grained, sheared, serpentinite matrix (foliated 'scaly' texture in Fig. 5b). In general, matrix prevails over the clasts. Nevertheless, the ophiolitic melange is polymictic in a few outcrops, including also clasts of basalt, chert and rare gabbro. Metric- to hectometric-sized ophiolitic olistoliths (often brecciated, i.e. 'block-block' type) are also common ('of' in MTA, 2002) (Fig. 5c). Locally, they are also represented by portions of the pristine stratigraphic succession consisting of: (a) serpentinite, cross-cut by microgabbro dykes (Fig. 5d) and by veins of chalcedony or by Fe-rich, concretionary or fibrous calcite; (b) stratified pelagic Calpionella-like limestones (Fig. 5e), sometimes with basal cherts and basalts; (c) pillow lavas 


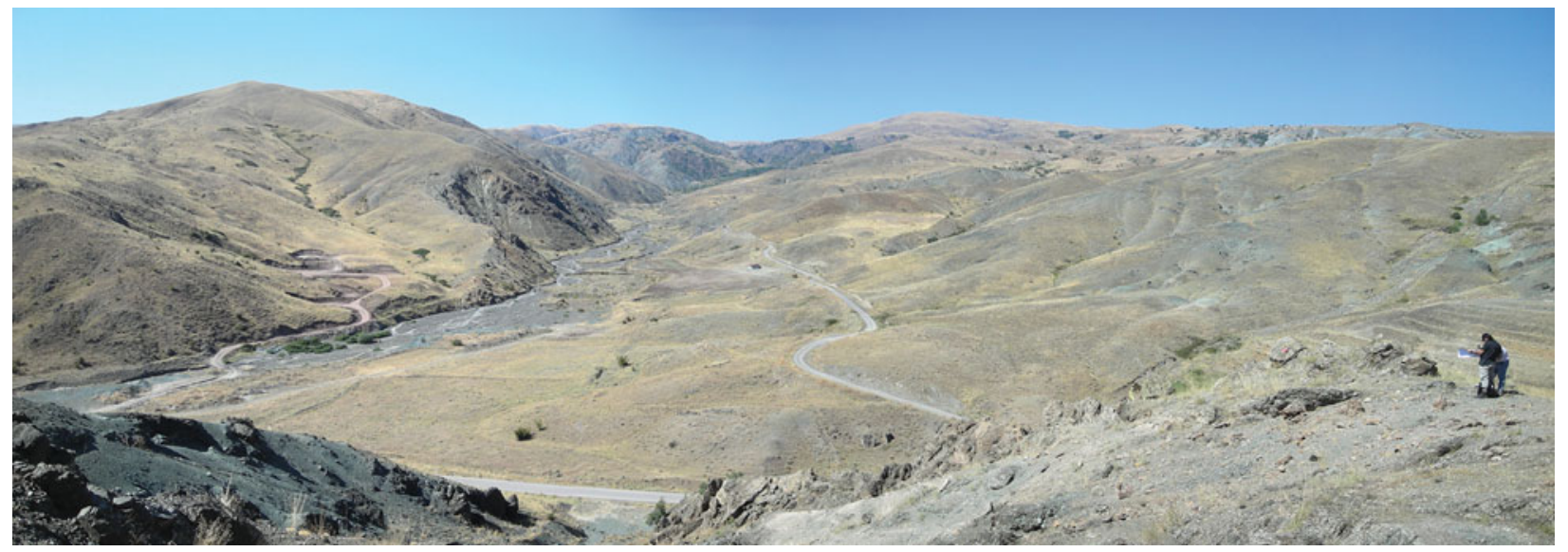

Figure 4. (Colour online) The Kizilirmak Valley south of Kalecik.

(rarely characterized by a pink-reddish, radiolarianbearing micrite matrix, Fig. 5f) with locally manganesiferous cherts at the top. Moreover, levels of sedimentary breccia with ophiolitic and reddish to pink carbonate clasts (Fig. $5 \mathrm{~g}$ ) or, rarely, with only ophiolitic components (Fig. 5h) were locally identified, especially within the cherty successions.

The AOM of the transect 'of2' (see Fig. 2a) tectonically overlies a stratified conglomerate, sandstone and shale flysch unit that is mapped as the Paleocene 'pm' in MTA (2002) and as the Upper Cretaceous 'kk' Karadağ Formation + 'ks' Samanlik Formation and Paleocene Dizlltaşlar Formation in MTA (2010). These Cretaceous-Paleocene sediments are mapped in Figure 2a as 'cp'. To the east these units thrust over the 'e' Eocene clastic and carbonate succession (MTA, 2002) that unconformably overlies the CACC. The 'cp' clastic unit is also tectonically below the AOM in the tectonic inlier crossed by transect 'c' west of Kösrelik village (e.g. Fig. 2a; see also MTA, 2010). Other features of the AOM are listed below:

(1) Megaolistoliths or tectonic slices of serpentinite, basalt and minor gabbro can be locally found, particularly at the top of the melange (Fig. 5i) (e.g. the gabbro and serpentinite slices at the top of transect 'of 1'; see also MTA, 2010).

(2) Shear zones, characterized by different types of cataclasite and mylonites, are often recognizable at different levels in the melange (Fig. 5j). They are more common in the upper part of the AOM and within or at the top of megaolistoliths and tectonic wedges (see also structural data).

(3) Blue amphibole was observed in foliated breccias with elements of serpentinite and basalt at the contact with the overlying Mesozoic carbonates along transect ' $h$ ' south of Çorum (in area B2, Fig. 2c).

(4) At the southern end of transect 'd' (Fuadiye village in Fig. 2b), the AOM includes a pluridecametrical/hectometrical body of a calcareousmarly flysch under a thick olistolith of pillow lavas and cherts. This flysch succession is made up of alternating graded calcareous sandstones, impure biocalcarenites, marly limestone, more or less calcareous marls and marly shales. Microscopic analyses of the calcareous rocks show the presence of a pelagic fossil association (small Globigerinidae, Ticinella sp., Rotalipora sp., Rotalipora appenninica, R. cushmani and Praeglobotruncana sp. and small Globotruncanidae) that points to an early Late Cretaceous (Cenomanian) sedimentation age. Similar rocks, associated with varicoloured shales, cherts and ophiolitic breccias, are also present in the AOM of the tectonic window in the Kösrelik village area in transect 'c' (area A, Fig. 2a).

(5) Another huge flysch-type body, hectometric to kilometric in size, crops out along the road from Çorum to Alaca (see asterisks in transect ' $\mathrm{g}$ ' in Fig. 2c). This sedimentary succession was previously attributed to the Sakarya units ('pt' in MTA, 2002; 't2t3-10s' in MTA, 2010), but our study reveals that it is an intercalation (megaolistolith or tectonic slice) within the AOM. This flysch is not so different to that exposed in transect ' $d$ ' consisting of centimetre/decimetre-thick alternations of grey limestone, marly limestone, biocalcarenites and laminated quartzose greywackes with grey to greybrownish shales and marly shales (Fig. 5k). A Cretaceous (Cenomanian) age has also been attributed to this sedimentary succession, based on the fossil association of small Globigerinidae, Radiolaria and Pithonella ovalis.

(6) Olistoliths of often massive carbonate rock successions, consisting of grey, grey-brown to dark grey limestone of uncertain stratigraphic and palaeogeographic location (olistoliths from a Mesozoic carbonate platform?) are locally present in the AOM, e.g. in the surroundings of Büyükhırka village along transect ' $\mathrm{f}$ ', SSW of Alaca (area B1, Fig. 2b).

\section{4.a.2. The Sakarya Zone}

The Sakarya Zone is made up of prevalent low-grade metamorphic and rarely highly diagenetic units (i.e. the Palaeozoic-Triassic 'pt' and 'ş' in MTA, 2002). 

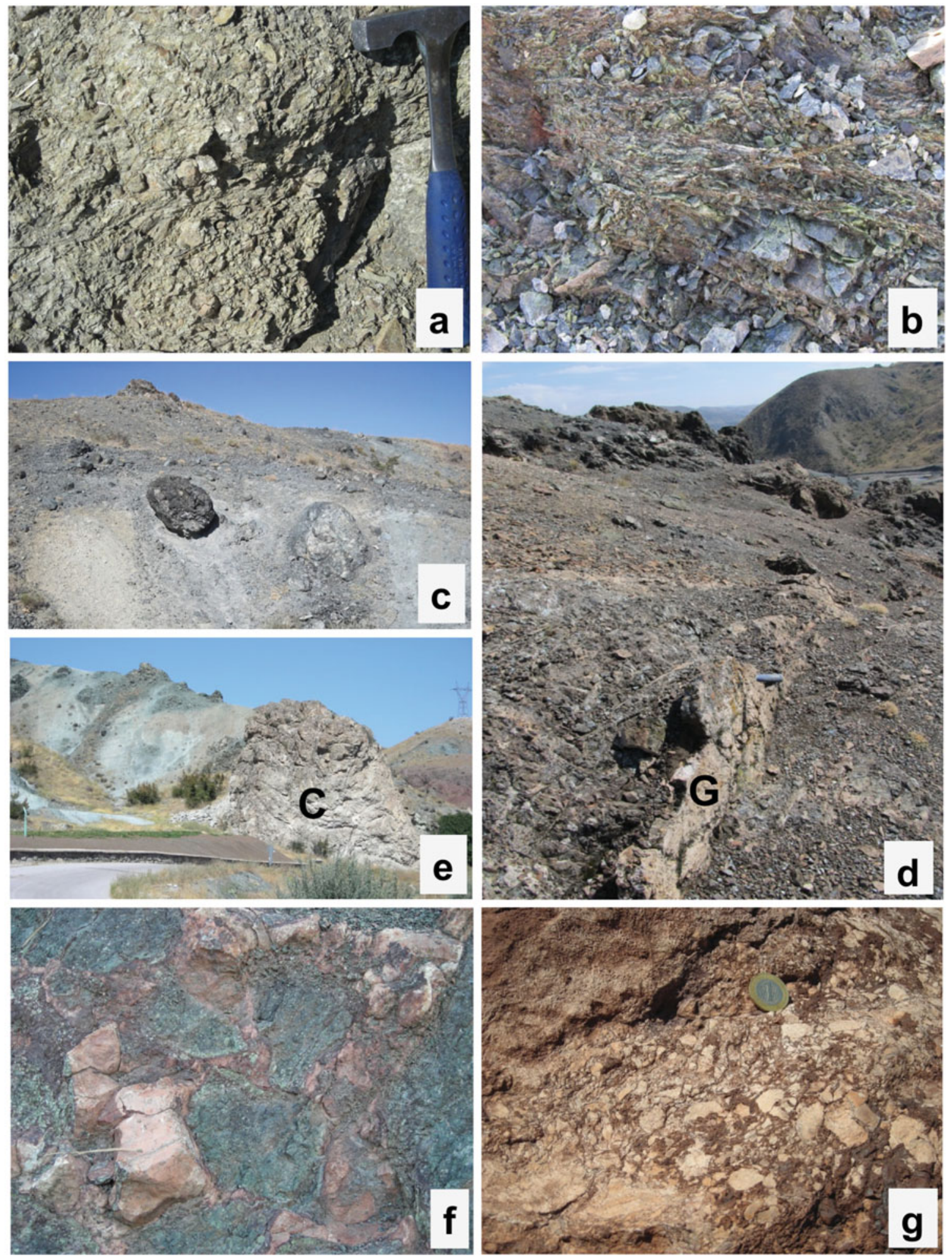

Figure 5. (Colour online) (a) Brecciated serpentinite in a granular to often finely sheared serpentinite matrix (transect 'of2' in Fig. 2a). (b) Foliated serpentinite matrix characterized by 'scaly' texture (magnified from Fig. 5a). (c) Metric-sized serpentinite olistoliths in the AOM melange (transect 'of1' in Fig. 2a). (d) Microgabbro dyke (G) within a brecciated serpentinite megaolistolith (transect 'of2'). (e) Megaolistolith of stratified pelagic Calpionella-like limestones (C) (transect 'of2'). (f) Pillow lavas with a pink-reddish, radiolarianbearing micrite matrix (transect 'of1'). (g) Sedimentary breccia with ophiolitic and prevailing reddish to pink carbonate clasts (transect 'of2'). Hammer for scale is $33 \mathrm{~cm}$ long and coin is $2 \mathrm{~cm}$ diameter. 

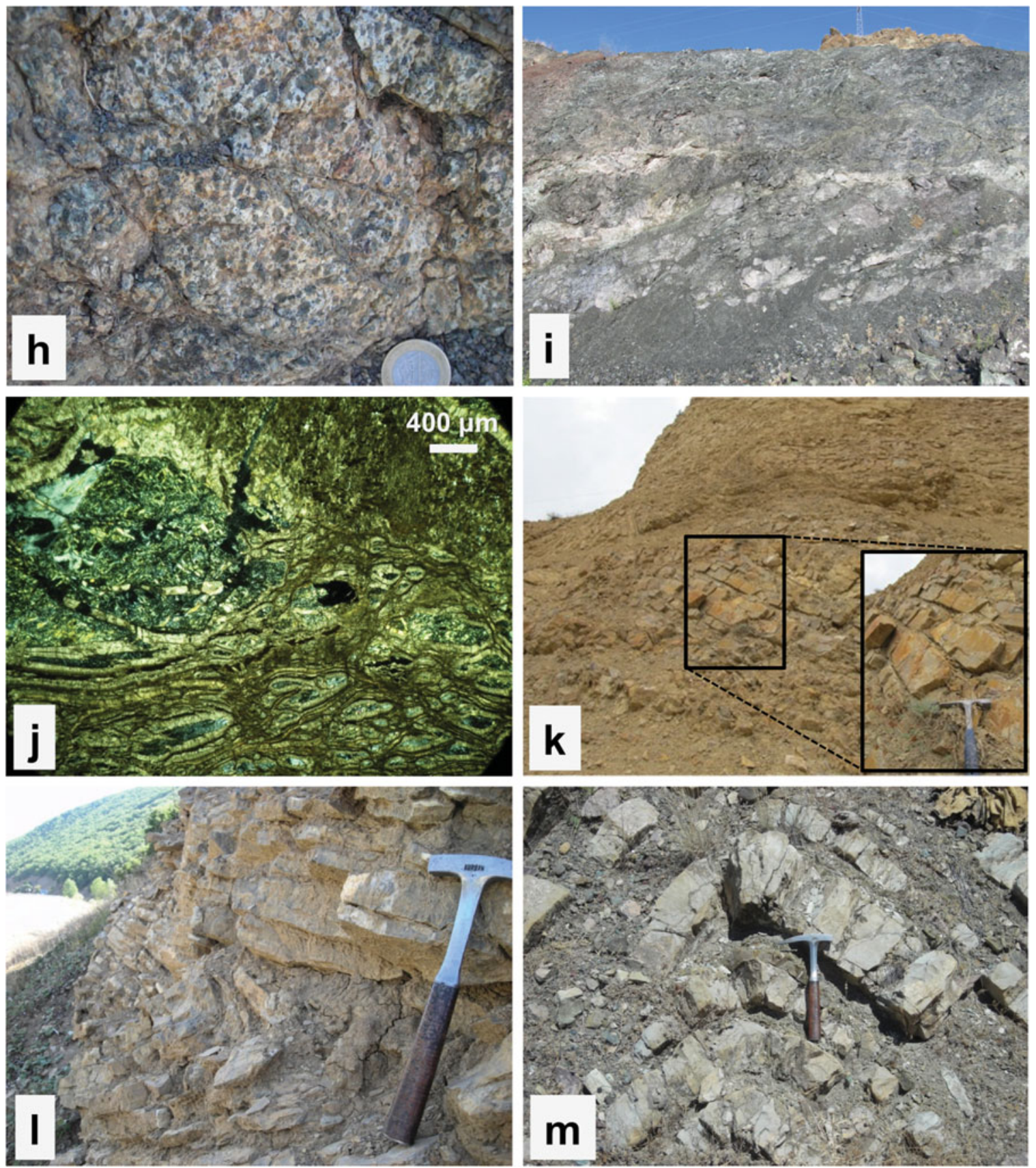

Figure 5. (Continued) (Colour online) (h) Monomictic sedimentary ophiolitic breccias (transect 'ofl'). (i) Serpentinite slice at the top of AOM melange (transect 'ofl'). (j) Photomicrograph of calcite fibre-rich serpentinite mylonite horizon in a serpentinite brecciated megaolistolith (transect 'of2'), crossed polars. (k) Alternating marly limestones, biocalcarenites and quartzose greywacke beds with shales and marly shale intercalations of the flysch-like succession along the Çorum-Alaca road (transect 'g' in Fig. 2b). (l) SE-vergent, recumbent folds in the flysch-like succession along the Çorum-Alaca road (transect ' $\mathrm{g}$ ' in Fig. 2b). (m) Symmetric folds with N40directed axis in a megaolistolith of the Calpionella-like limestone (transect 'of2').

They underlie Mesozoic to Tertiary carbonate formations that rarely show evidence of recrystallization or metamorphism (e.g. the Middle-Upper Triassic ' $t_{2-3}$ ', and the Upper Jurassic - Lower Cretaceous ' $\mathrm{j}_{3}-\mathrm{k}_{1}$ ' in MTA, 2002). According to our data, three main tectonostratigraphic units (BAA, BKC and AMC in Figs 2,3) can be distinguished in the studied Sakarya Zone complex:

(1) The Bozca-Akyurt-Avciova (BAA) unit. Three main members can be distinguished in the BAA unit that crops out in the areas to the east of Ankara (transects ' $a$ ', ' $b$ ' and 'c' in Fig. 2a) to those of the surroundings of Çorum-Alaca (transects 'd', 'e', 'f', 'h' and 'i', Fig. 2b, c, d):

(a) The Lower Member is exposed along transect ' $b$ ' and in MTA (2002) and was mapped as 'ş'. It is mainly made up of well-bedded (up to $2.5 \mathrm{~m}$ thick), medium- to coarse-grained quartzitic metasandstones and metagreywackes that are sometimes characterized by microconglomerate erosional bases. The beds are 
separated by thin (generally centimetric) layers of grey to black sericitic and sericitic-chloritic phyllite. In places, minor impure grey to black metacalcarenites and calcschists also occur.

(b) The Intermediate Member is dominant in the Ankara-Çorum area and has good outcrops along transect 'b' and 'c'. It was mapped as 'pt' in MTA (2002) and consists of an alternation of shiny, grey to black phyllite and metasiltstone with decimetric up to $1.5 \mathrm{~m}$ thick intercalations of grey fine- to coarse-grained metasandstones.

(c) The Upper Member, mostly mapped as 's' in MTA (2002), is made up of prevalent grey metalimestones and calcschists with phyllitic intercalations that pass upwards to alternations of varicoloured (grey, green to violet-reddish) phyllite, whitish to greypinkish marble and cherty marble, and grey-violet to greenish calcschist.

It worth noting that in transects ' $a$ ' and ' $b$ ' the metasiliciclastic rocks are cross-cut by nonmetamorphic intermediate-basic magmatic dykes (essentially tonalite-diorite to gabbro), up to $6 \mathrm{~m}$ in thickness, whose ages are Late Triassic (according to MTA, 2010), and that are not present in the overlying Mesozoic carbonate cover formations (e.g. ' $t_{2-3}$ ').

The petrographic features of the BAA members are shown in Table 1 (location of the samples in Fig. 2a, $\mathrm{b}, \mathrm{c})$. Photomicrographs of the abovementioned three members are shown in Figure 6a, b, c, d.

(2) The Boyaci-Kertme-Çayan (BKC) unit. This unit (mapped as 'ş' in MTA, 2002) crops out only to the SE of Çorum in the B2 area (transects ' $\mathrm{i}$ ' and ' $\mathrm{j}$ ' in Fig. 2c) where it tectonically rests below the BAA. The BKC is made up of grey to greygreenish garnet-bearing, at times quartzitic micaschist (Fig. 6e, f) and dark green metabasite and amphibolitic gneiss (Fig. 6g, h). The metabasite locally prevails over the other lithotypes. Moreover, whitish to yellowish coarse-grained marble with micaschist intercalations can be locally found generally as tectonic slices in the upper part of the unit (e.g. transect 'i', see Fig. 3). These rocks are generally characterized by distinctively coarse-grained foliation, compared to the other studied greenschist-facies lithologies of the BAA and AMC, and often include glaucophane (Gln) relics recognizable to the naked eye. It is also worth noting the presence of some tectonic intercalations of serpentinite to the WSW of Boyac1 village (see also MTA, 2002). Preliminary surveys allow us to also define the presence of the BKC rocks in the areas towards the $\mathrm{E}$ and ENE of Çorum.

The petrographic features of the $\mathrm{BKC}$ are shown in Table 2 (location of the samples in Fig. 2c).

(3) The Amasya-Mahmatlar-Cayrak (AMC) unit. Three main members can be defined in the transects ' $\mathrm{k}$ ', ' $\mathrm{l}$ ' and ' $\mathrm{m}$ ' of the AMC (mapped as 's ' in MTA, 2002), but, at present, we do not have sufficient data to map them in the studied areas:

(a) The Lower Member crops out in the surroundings of Mahmatlar village immediately above the tec- tonic contact with the underlying AOM. This member is made up of alternating grey metagreywacke and meta-arkose with grey-silver phyllite intercalations similar to the corresponding lithotypes of the BAA.

(b) The Intermediate Member consists of varicoloured phyllites with levels of marble and calcschist.

(c) The Upper Member is represented by a thick succession of green chlorite-sericite phyllites and quartzites, greenschist-facies metavolcanites and metavolcaniclastic rocks with local intercalations of foliated grey marble, grey-green calcschist and varicoloured (violet, grey-greenish, reddish) phyllite. The metavolcanites locally preserve pillow-lava structures and often show relics of magmatic microaugen texture, due to polysynthetic-twinned, acidic plagioclase and sanidine porphyroclasts and aggregates of chlorite (after femic phenocrysts) in a microquartziticchloritic groundmass (likely deriving from a more or less altered vitrophyric groundmass).

Gln relics within the dominant greenschist-facies framework were also defined in a metavolcanite sample (sample 41a).

The petrographic features of the AMC are summarized in Table 3 (location of the samples in Fig. 2d). Photomicrographs of the abovementioned three members are shown in Figure 6i, j.

\section{4.a.3. Relationships with the Mesozoic carbonate cover sequences}

These Triassic (' $t_{2-3}$ ') and Jurassic - Lower Cretaceous (e.g. ' $\mathrm{j}_{3}-\mathrm{k}_{1}$ ') carbonate platform successions rest above the BAA and AMC, respectively, through sharp contacts. These carbonate successions are generally massive, but in some places they preserve a basal part characterized by alternations of different non-metamorphic lithotypes in which the original sedimentary textures and fossil content are generally well preserved.

For example in transect ' $\mathrm{a}$ ', the $c .100 \mathrm{~m}$ thick basal part of the Triassic ' $t_{2-3}$ ' (see Fig. 3) is made up of stratified (up to $1.5 \mathrm{~m}$ thick), black to dark grey carbonate platform limestones with minor pelitic interbeds. The limestone is essentially a fenestrae dismicrite with pellets, calcareous algae, small pelecypods and agglutinated foraminifera. This carbonate sequence includes at least four metric to decametric horizons of pillow lavas, often characterized by a variolic texture, and ialoclastites. More to the east, this unit changes into a centimetre-decimetre alternation of black to dark grey silty limestone, calcarenites and shales. The succession continues upwards with centimetre-bedded, nodular grey to pink-reddish, at times micritic cherty limestones (including Radiolaria and minor ostracods and pelecypods) and marly limestones, in places with volcanic/volcaniclastic horizons and possibly cherty intercalations in the upper part. Finally it vertically passes to poorly stratified to massive, grey and light grey limestone, often represented by 
Table 1. Synthesis table of petrographic data of the BAA, in the different transects

\begin{tabular}{|c|c|c|c|c|}
\hline $\begin{array}{l}\text { LOCALITY AND } \\
\text { NUMBER OF } \\
\text { SAMPLE }\end{array}$ & UNIT & LITHOLOGY & TEXTURE & COMPOSITIONAL FEATURES \\
\hline $\begin{array}{l}\text { Transect 'a' (1) } \\
\text { Transect 'c' (9e) } \\
\text { Transect 'd' (17, } \\
\text { 20d-e) }\end{array}$ & $\begin{array}{l}\text { BAAb } \\
(\mathrm{ex} \text { 'pt') }\end{array}$ & $\begin{array}{l}\text { Grey to black } \\
\text { phyllite and } \\
\text { silty phyllite }\end{array}$ & Lepidoblastic & $\begin{array}{l}\text { Ser }+\mathrm{Chl} \pm \mathrm{Qtz} \pm \mathrm{Grf}(\mathrm{C} \text { to } \mathrm{F}) \text {, sometimes } \pm \mathrm{Cc} \\
\mathrm{Local} \mathrm{Qtz}+\mathrm{Ser}+\mathrm{Ms}+\mathrm{Bt}+\mathrm{aPl} \pm \text { phyllite lithics and } \\
\text { graphite-rich siltstone discontinuous layers } \\
\text { Post-tectonic Feox/hyox veins }\end{array}$ \\
\hline $\begin{array}{l}\text { Transect 'a' (1a) } \\
\text { Transect 'c' (9b) } \\
\text { Transect 'd' (16 c) }\end{array}$ & $\begin{array}{l}\text { BAAb } \\
(\mathrm{ex} \text { 'pt') }\end{array}$ & Metasiltstone & $\begin{array}{l}\text { Fine-grained } \\
\text { blastopsammitic }\end{array}$ & $\begin{array}{l}\text { Ser }+ \text { Chl (generally penninite) } \pm \text { Grf including grains of } \\
\text { Qtz, Ms and Chl (after Bt) flakes and aggregates } \\
\text { Local millimetric Qtz-rich, fine-grained metasandstone } \\
\text { levels } \\
\text { Acc. min.: Tiox } \\
\text { Post-tectonic Feox/hyox veins }\end{array}$ \\
\hline $\begin{array}{l}\text { Transect 'a' } \\
(1 \mathrm{~b}, 2 \mathrm{c}) \\
\text { Transect 'c' } \\
(9 \mathrm{a}, 9 \mathrm{c}) \\
\text { Transect 'd' } \\
\quad(16 \mathrm{a}, 16 \mathrm{~b}, 18)\end{array}$ & $\begin{array}{l}\text { BAAb } \\
(\mathrm{ex} \text { 'pt') }\end{array}$ & $\begin{array}{l}\text { Coarse- to } \\
\text { medium- } \\
\text { grained } \\
\text { metasandstone }\end{array}$ & $\begin{array}{l}\text { Low sorted, } \\
\text { blastopsammitic }\end{array}$ & $\begin{array}{l}\text { Lithic to lithic-feldspathic metagreywackes with } \\
\text { Ser }+\mathrm{Chl} \pm \mathrm{Qtz} \pm \mathrm{Ab} \pm \text { Grf matrix and a few Cc cement } \\
\text { Angular to sub-rounded grains of: } \\
\text { - mono- and polycrystalline Qtz (mainly with undulose } \\
\text { extinction) (F to FF) } \\
\text { - tt aPl (C to C-R) } \\
\text { - Ms and Chl (sometimes after Bt) flakes (C) } \\
\text { - Often decoloured/chloritized Bt (C-R) } \\
\text { Lithics: } \\
\text { - Acidic volcanic rocks (C) (microquartzites locally with } \\
\text { fluidal texture and Qtz xenocrysts; ipocrystalline } \\
\text { metadacite/ryodacite with embayed quartz and aPl } \\
\text { xenocrysts) } \\
\text { - Basalts to dacites (generally R) } \\
\text { - Metamorphic (C) (Ms-Chl quartzites; Ser }+ \text { Chl } \pm \text { Qtz, } \\
\text { Grf-rich phyllites; Ms }+ \text { Chl } \pm \text { Qtz micaschists) } \\
\text { - Plutonic (R) (granular ipidiomorphic ttt aPl + ut and t Kfs } \\
\text { (often } \pm \text { sericitized)+Qtz } \pm \text { Chl (after Bt) } \\
\text { Acc. min.: Zr, Ttn, Tiox, Grf } \\
\text { Local Grf-rich phyllites discontinuous layers (recrystallized } \\
\text { 'clay chips' or transposed phyllitic levels) } \\
\text { Post-tectonic Cc veins }\end{array}$ \\
\hline Transect 'c' $(9 \mathrm{~d})$ & $\begin{array}{l}\text { BAAb } \\
(\mathrm{ex} \text { 'pt') }\end{array}$ & $\begin{array}{l}\text { Silty meta-marl/ } \\
\text { carbonate } \\
\text { phyllite }\end{array}$ & $\begin{array}{l}\text { Lepidoblastic, at } \\
\text { times microaugen }\end{array}$ & $\begin{array}{l}\text { Ser }+\mathrm{Cc}+\mathrm{Grf} \\
\text { Including Qtz, t and tt aPl (locally } \\
\text { sub-idiomorphic } \pm \text { calcitized) and Cc microaugens } \\
\text { Post-tectonic Qtz }+ \text { Py veins cut by late Cc veins }\end{array}$ \\
\hline $\begin{array}{l}\text { Transect 'b' (13a, } \\
\quad 13 \mathrm{~b}, 13 \mathrm{c})\end{array}$ & $\begin{array}{l}\text { BAAa } \\
(\mathrm{ex} \text { 'ş') }\end{array}$ & $\begin{array}{l}\text { Coarse- to } \\
\text { medium- } \\
\text { grained } \\
\text { metasandstone }\end{array}$ & $\begin{array}{l}\text { Low sorted, } \\
\text { blastopsammitic }\end{array}$ & $\begin{array}{l}\text { Lithic to lithic-feldspathic metagreywacke with } \\
\text { Ser }+\mathrm{Chl} \pm \mathrm{Qtz} \pm \mathrm{Ab} \pm \text { Grf matrix and local Cc cement } \\
\text { Grains and lithics: idem to sample } 2 \mathrm{c} \text { in BAAb, but with } \\
\mathrm{C}-\mathrm{F} \text { aPl and meta-rhyolite lithics and embayed Qtz grains } \\
\text { Acc. min.: } \mathrm{Zr} \text {, Ttn, Tiox, Grf, Tur, Py } \\
\text { Post-tectonic veins of FeCc }+ \text { Qtz and Feox/hyox }\end{array}$ \\
\hline Transect 'd' (19) & $\begin{array}{l}\text { BAAc } \\
\left(\mathrm{ex} ' \mathrm{pt}^{\prime}\right)\end{array}$ & Calcschist & Granolepidoblastic & $\begin{array}{l}\text { Millimetric alternations of impure metalimestone (including } \\
\text { Qtz, Chl, Ms-Ser, Grf) and Grf-rich Ser-Chl phyllite } \\
\text { Acc. min.: Feox/hyox, Py (mostly oxidized) } \\
\text { Syn-tectonic (Syn } \mathrm{S}_{1} \text { ) FeCc }+ \text { Qtz veins } \\
\text { Inter-tectonic (between } \mathrm{D}_{1} \text { and } \mathrm{D}_{2} \text { ) Cc veins }\end{array}$ \\
\hline Transect 'd' (19a) & $\begin{array}{l}\text { BAAc } \\
\left(\mathrm{ex}^{\prime} \mathrm{pt} \text { ') }\right.\end{array}$ & $\begin{array}{l}\text { Medium- to } \\
\text { fine-grained } \\
\text { foliated marble }\end{array}$ & Granoblastic & $\begin{array}{l}\mathrm{Cc} \pm \mathrm{Qtz} \pm \mathrm{Ms} \pm \text { Grf } \\
\mathrm{Rare} \text { Ser } \pm \text { Grf phyllitic 'fishes' }\end{array}$ \\
\hline Transect ‘d’ (20a) & $\begin{array}{l}\text { BAAc } \\
(\mathrm{ex} \text { 'ş') }\end{array}$ & $\begin{array}{l}\text { Grey-violet } \\
\text { calcschist }\end{array}$ & Granolepidoblastic & $\begin{array}{l}\text { Alternation of fine-grained, foliated isoblastic marble } \\
\text { (locally including lens of Ser }+ \text { Hem phyllite), } \\
\text { coarse-grained heteroblastic foliated marble (with } \\
\text { scattered Qtz and } \pm \text { idiomorphic } \mathrm{Ab} \text { ) and } \\
\text { Ser }+ \text { Chl }+ \text { Hem phyllite } \\
\text { Acc. min.: Ep, Ttn }\end{array}$ \\
\hline Transect 'd' (20b) & $\begin{array}{l}\text { BAAc } \\
(\text { ex 'ş') }\end{array}$ & Green phyllite & Lepidoblastic & $\mathrm{Chl}+\mathrm{Qtz} \pm \mathrm{Ab} \pm \mathrm{Ep} \pm$ Hem with local Cc boudins \\
\hline Transect 'd' (20c) & $\begin{array}{l}\text { BAAc } \\
(\mathrm{ex} \text { 'ş') }\end{array}$ & $\begin{array}{l}\text { Varicoloured } \\
\text { marble }\end{array}$ & Granoblastic & $\begin{array}{l}\text { Fine-grained marble including a microquartzitic band (after } \\
\text { cherts) passing to impure calcschist (with scattered Qtz } \\
\text { and t } \mathrm{Ab} \text { ) and Chl }+ \text { Hem }+ \text { Tiox phyllite } \\
\text { Post-tectonic } \mathrm{Cc} \pm \mathrm{Qtz} \text { veins }\end{array}$ \\
\hline
\end{tabular}

Locations of the transects and of the samples in Figure 2a, b, c. Abbreviations: Qtz - quartz; Ser - sericite; Ms - muscovite; Bt - biotite; Ab - albite; aPl - acidic plagioclase; iPl - intermediate plagioclase; Kfs - k-feldspar; Sa - sanidine; Chl - chlorite; $\mathrm{Cc}$ - calcite; FeCc - iron-rich calcite; Grf - graphite and organic matter 1.s.; Zr - zircon; Ap - apatite; Ep - epidote; Ttn - sphene; Feox/hyox - Fe oxides and hydroxides; Rt - rutile; Hem - haematite; Py - pyrite; Tiox - titaniferous oxides; Gln - blue amphibole; Grt - garnet; Hbl - hornblende; Tre - tremolite; Tur - tourmaline.

ut - untwinned; $\mathrm{t}$ - simple twin; $\mathrm{tt}$ - polysynthetic twins; $\mathrm{ttt}$ - albite-carlsbad twins; FF - very abundant; $\mathrm{F}$ - abundant; $\mathrm{C}$ - common; $\mathrm{R}$ rare; acc. min. - accessory minerals. 
Table 2. Synthesis table of petrographic data of the BKC

\begin{tabular}{|c|c|c|c|c|}
\hline $\begin{array}{l}\text { LOCALITY AND } \\
\text { NUMBER OF } \\
\text { SAMPLE }\end{array}$ & UNIT & LITHOLOGY & TEXTURE & COMPOSITIONAL FEATURES \\
\hline Transect 'i' (32a) & $\begin{array}{l}\text { BKC } \\
\text { (ex 'ş’) }\end{array}$ & $\begin{array}{l}\text { Metabasite/ } \\
\text { amphibolitic } \\
\text { gneiss }\end{array}$ & $\begin{array}{l}\text { Nematoblastic/ } \\
\text { diablastic to } \\
\text { granoblastic }\end{array}$ & $\begin{array}{l}\text { tt aiPl (locally sericitized) }+\mathrm{Qtz}+\mathrm{Ms}+\mathrm{Cc}+\mathrm{Gln} \\
\quad \text { (also } \pm \text { idiomorphic and locally chloritized) }+\mathrm{Chl} \pm \mathrm{Bt} \\
\text { Acc. min.: Ttn (C), Py, Ep, Ap } \\
\text { Post-tectonic Cc veins }\end{array}$ \\
\hline $\begin{array}{l}\text { Transect 'i' }(32 \mathrm{a} \\
\text { bis) } \\
\text { Transect 'j' } \\
(33 \mathrm{c})\end{array}$ & $\begin{array}{l}\text { BKC } \\
\text { (ex 's’') }\end{array}$ & $\begin{array}{l}\text { Gln- and } \\
\text { Grt-bearing } \\
\text { micaschist }\end{array}$ & $\begin{array}{l}\text { Granolepidoblastic/ } \\
\text { porphyroblastic }\end{array}$ & $\begin{array}{l}\text { Qtz }+\mathrm{Ms}+\mathrm{Cc}+\text { ut to } \mathrm{Ab}+\mathrm{Gln} \text { (locally stretched, } \pm \\
\left.\text { chloritized and included in } \mathrm{S}_{1}\right) \pm \mathrm{Bt}+\mathrm{Chl} \text { (later, } \\
\text { probably after } \mathrm{Bt}) \\
\text { Gln porphyroclasts with } \mathrm{Bt}+\mathrm{Chl}+\mathrm{Qtz}+\mathrm{Ab} \text { pressure } \\
\text { shadows and local inclusion trails, perpendicular to the } \\
\text { blast boundaries, of opaque and fibrous (e.g. Rt) minerals } \\
\text { Syn- } \mathrm{D}_{1} \text { porphyroblasts: } \\
\text { - Grt (granular to sub-idiomorphic), includes } \mathrm{S}_{1} \text { foliation } \\
\text { (essentially Qtz } \pm \mathrm{Ab}) \\
\text { - t } \mathrm{Ab} \text {, locally with } \mathrm{Rt}+\mathrm{Ttn} \pm \mathrm{Ap} \text { inclusion trails } \\
\text { Acc. min.: Ttn }(\mathrm{C}), \mathrm{Py}, \mathrm{Ep}(\mathrm{C}), \mathrm{Ap}, \mathrm{Rt}, \mathrm{Hem} \\
\text { Post-tectonic } \mathrm{Cc} \text { veins }\end{array}$ \\
\hline $\begin{array}{l}\text { Transect ' } \mathrm{i} \text { ' (32tris) } \\
\text { Transect 'j' } \\
(33 \mathrm{~d}, 33 \mathrm{e})\end{array}$ & $\begin{array}{l}\text { BKC } \\
(\mathrm{ex} \text { 's’) }\end{array}$ & Metabasite & Nematoblastic & $\begin{array}{l}\text { ut to } \mathrm{t} \mathrm{Ab}+\mathrm{Chl}+\mathrm{Gln} \text { (mostly altered in } \\
\mathrm{Chl})+\mathrm{Cc} \pm \mathrm{Qtz} \pm \mathrm{Bt} \pm \mathrm{Hbl}(\text { also as rim of Gln) } \\
\text { Gln porphyroclasts with } \mathrm{Bt}+\mathrm{Chl}+\mathrm{Qtz}+\mathrm{Ab} \text { pressure } \\
\text { shadows } \\
\text { Ttn }+ \text { Ep trails } / / \mathrm{S}_{1} \\
\text { Acc. min.: Ep }(\mathrm{C}), \mathrm{Ttn}, \mathrm{Py} \text {, Tiox } \\
\text { Syn-tectonic Cc }+ \text { polycrystalline Qtz } \\
\text { Post-tectonic Cc veins }\end{array}$ \\
\hline Transect 'i' (32b) & $\begin{array}{l}\text { BKC } \\
\text { (ex 'ş’) }\end{array}$ & Metabasite & $\begin{array}{l}\text { Granolepidoblastic/ } \\
\text { Porphyroblastic to } \\
\text { locally mylonitic }\end{array}$ & $\begin{array}{l}\text { ut to } \mathrm{Ab}+\mathrm{Qtz}+\mathrm{Chl}+\mathrm{Cc}+\mathrm{Ms}+\mathrm{Ep} \\
\text { Rare } \pm \text { chloritized Gln relics } \\
\text { Syn- } \mathrm{D}_{1} \text { porphyroblasts: } \\
\text { - aggregates of Ep (with RR Gln inclusions) and } \\
\mathrm{Ep} \pm \mathrm{Ab} \pm \mathrm{Cc} \\
\text { Acc. } \min .: \text { Ep }(\mathrm{C}), \mathrm{Ttn}, \text { Tiox }\end{array}$ \\
\hline Transect 'i' (32c) & $\begin{array}{l}\text { BKC } \\
(\text { ex 'ş') }\end{array}$ & Foliated marble & $\begin{array}{l}\text { Granoblastic/ } \\
\text { heteroblastic }\end{array}$ & $\begin{array}{l}\text { Impure marble (including Qtz, ut to t } \mathrm{Ab}, \mathrm{Ms} \text {, Hem and/or } \\
\text { Py) } \\
\text { Local discontinuous levels of Ser/Ms } \pm \mathrm{Cc} \pm \mathrm{Feox} / \mathrm{Py}\end{array}$ \\
\hline Transect 'i' (32d) & $\begin{array}{l}\text { BKC } \\
\text { (ex 'ş') }\end{array}$ & $\begin{array}{l}\text { Quartzitic } \\
\text { micaschist }\end{array}$ & Granolepidoblastic & $\begin{array}{l}\mathrm{Qtz}+\text { ut to } \mathrm{t} \mathrm{Ab}+\mathrm{Ms}+\mathrm{FeCc}+\mathrm{Bt} \text { (often chloritized) } \pm \\
\text { Chl (later) } \\
\text { Acc. min.: Ep, Ttn, Py } \\
\text { Impregnations and veins of } \mathrm{Fe} \mathrm{ox} / \text { Hyox }\end{array}$ \\
\hline
\end{tabular}

Locations of the transects and of the samples shown in Figure 2c. Abbreviations as in Table 1.

Table 3. Synthesis table of petrographic data of the AMC

\begin{tabular}{|c|c|c|c|c|}
\hline $\begin{array}{l}\text { LOCALITY AND } \\
\text { NUMBER OF } \\
\text { SAMPLE }\end{array}$ & UNIT & LITHOLOGY & TEXTURE & COMPOSITIONAL FEATURES \\
\hline $\begin{array}{c}\text { Transect ' } k \text { '(basal } \\
\text { part })(44 a, 44 b)\end{array}$ & $\begin{array}{l}\mathrm{AMCa} \\
(\mathrm{ex} \text { 'ş') }\end{array}$ & $\begin{array}{l}\text { Medium to very } \\
\text { coarse-grained } \\
\text { metasandstone }\end{array}$ & $\begin{array}{l}\text { Low sorted, } \\
\text { blastopsammitic } \\
\text { to blastopsephitic }\end{array}$ & $\begin{array}{l}\text { Feldspathic metagreywackes with Ser }+\mathrm{Chl}+\mathrm{Qtz} \\
\pm \mathrm{Ab} \pm \text { Grf matrix } \\
\text { Angular to sub-rounded grains of: } \\
\text { - mono- and polycrystalline Qtz (mainly monocrystalline } \\
\text { with undulose extinction and minor with straight } \\
\text { extinction and embayed) (F to FF) } \\
\text { - tt aPl (locally } \pm \text { sericitized) (C-F) } \\
\text { - Ms flakes and aggregates (C) } \\
\text { - Kfs (perthitic orthose and minor microcline) (C-F) } \\
\text { Lithics: } \\
\text { - Metamorphic (quartzites, Ser }+ \text { Chl phyllite) } \\
\text { - plutonic made up of granitoids (Qtz }+ \text { ttt aiPl } \pm \text { Cc and } \\
\text { Qtz+ ttt aiPl }+ \text { ut to t Kfs (perthitic orthose, locally } \\
\text { including small Ab) } \\
\text { Acc. min.: Py ( } \pm \text { oxidized), Hem, Ap, Zr } \\
\text { Syn-tectonic Qtz ribbons; post-tectonic Cc and Qtz veins }\end{array}$ \\
\hline $\begin{array}{l}\text { Transect ' } k \text { ' } \\
\text { (middle and } \\
\text { upper part)(35a) }\end{array}$ & $\begin{array}{l}\text { AMCc } \\
(\mathrm{ex} ' s ̧ ')\end{array}$ & $\begin{array}{l}\text { Green phyllite } \\
\text { (metabasite) }\end{array}$ & $\begin{array}{l}\text { Lepidoblastic/ } \\
\text { microaugen }\end{array}$ & $\begin{array}{l}\mathrm{Chl}+\mathrm{Ser} \pm \mathrm{Qtz} \pm \mathrm{Cc} \pm \mathrm{aPl} \pm \mathrm{Tr}-\mathrm{Act} \\
\text { Microaugens of: } \\
-\mathrm{tt} \text { aPl }\end{array}$ \\
\hline $\begin{array}{l}\text { Transect ' } 1 \text { ' (basal } \\
\text { part) }(36,38 a)\end{array}$ & & & & $\begin{array}{l}\text { - lenticular shaped aggregates of } \mathrm{Cc} \pm \mathrm{Qtz} \pm \mathrm{aPl}, \mathrm{aPl}+\mathrm{Tr} \text {, } \\
\mathrm{FeCc} \pm \mathrm{Qtz} \text { and } \mathrm{Chl}+\mathrm{Qtz}+\mathrm{Cc}\end{array}$ \\
\hline Transect 'm' (45) & & & & $\begin{array}{l}\text { Acc. } \min .: \text { Tiox } \\
\text { Local impregnations of Fe Ox/Hyox }\end{array}$ \\
\hline
\end{tabular}


Table 3. Continued

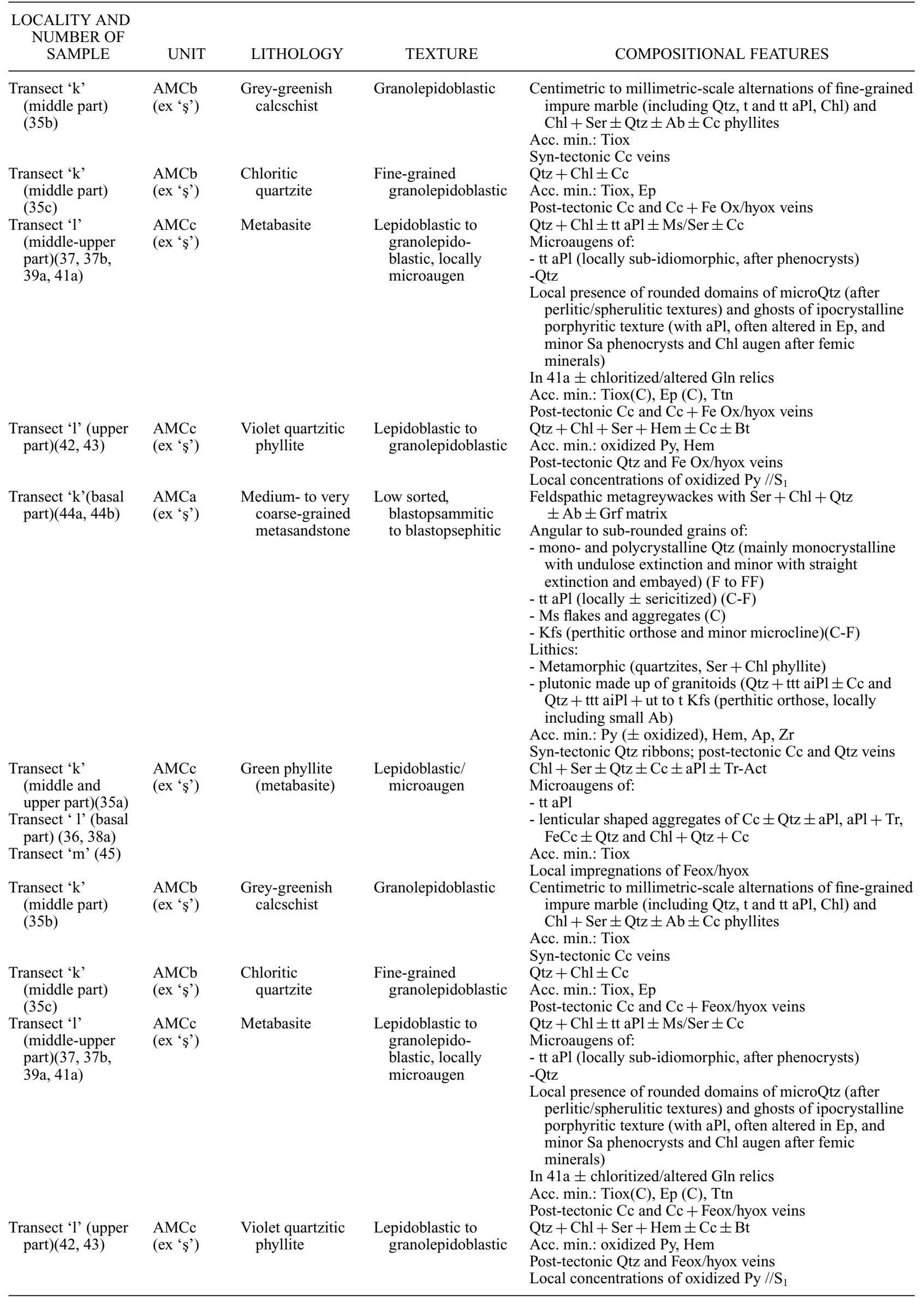



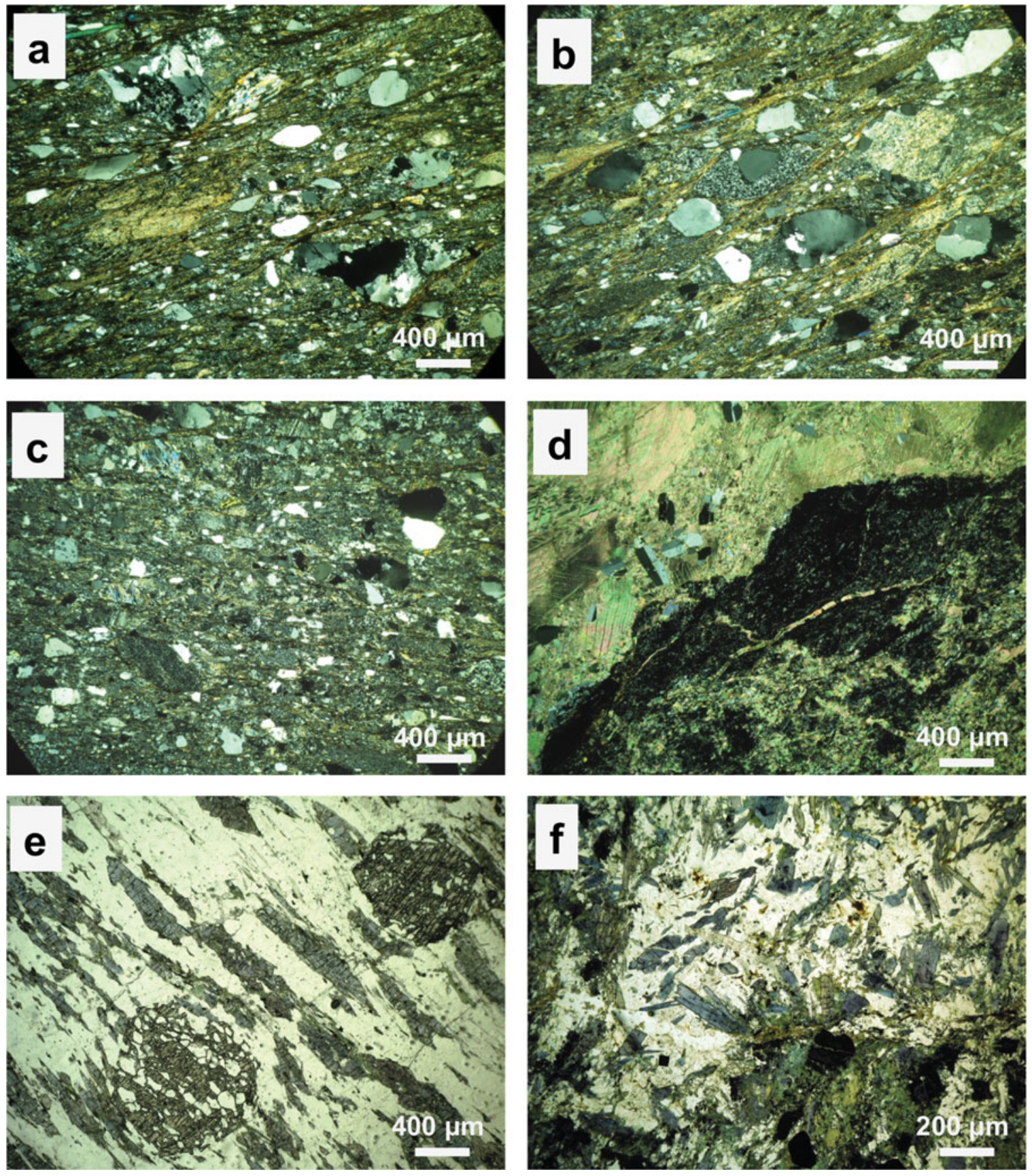

Figure 6. (Colour online) Photomicrographs of the Sakarya Zone rocks: (a) BAAb metagreywackes including metamorphic lithic grains at Akyurt (transect 'a'); (b) BAAb metagreywackes including volcanic lithic grains at Akyurt (transect 'a'); (c) BAAa metagreywackes at Bozca (transect 'b'); (d) contact between impure marble and haematite-rich phyllite in BAAc calcschists at Aydincık (transect 'd'); (e) BKC garnet-bearing micaschist and (f) metabasite both including blue amphibole relics at Boyac1 (transect 'i'). Crossed polars, except (e) with one polar.

mudstone to packstone with intraclasts (' $t_{2-3}$ ' body in MTA, 2002).

The basal sharp contact of the carbonate cover sequences is underlined by a lack of recrystallization and foliations in the latter with respect to the significant metamorphic imprint of the underlying BAA and AMC rocks. In the literature, this boundary has been generally interpreted as stratigraphic, i.e. the unconformable stratigraphic contact due to the Cimmerian Orogeny (e.g. MTA, 2002, 2010), but locally it is clearly affected by tectonics (see Sections 4.c and 5 below).

\section{4.b. Mineral chemistry data}

Chemical analyses on the blue amphibole-bearing metamorphic rocks (micaschists and metabasite/ prasinite) sampled from the Boyac1 area were carried out on polished and carbon-coated sections using a JXA8600 microprobe at C.N.R. - Istituto di Geoscienze e Georisorse, U.O.S. Firenze. The analyses were performed using an accelerating voltage of $15 \mathrm{kV}$ and a beam current of $10 \mathrm{nA}$. Operating counting times for elements were $15 \mathrm{~s}(10 \mathrm{~s}$ only for $\mathrm{Na})$ on the peak and $5 \mathrm{~s}$ for each background. The acquired data were 

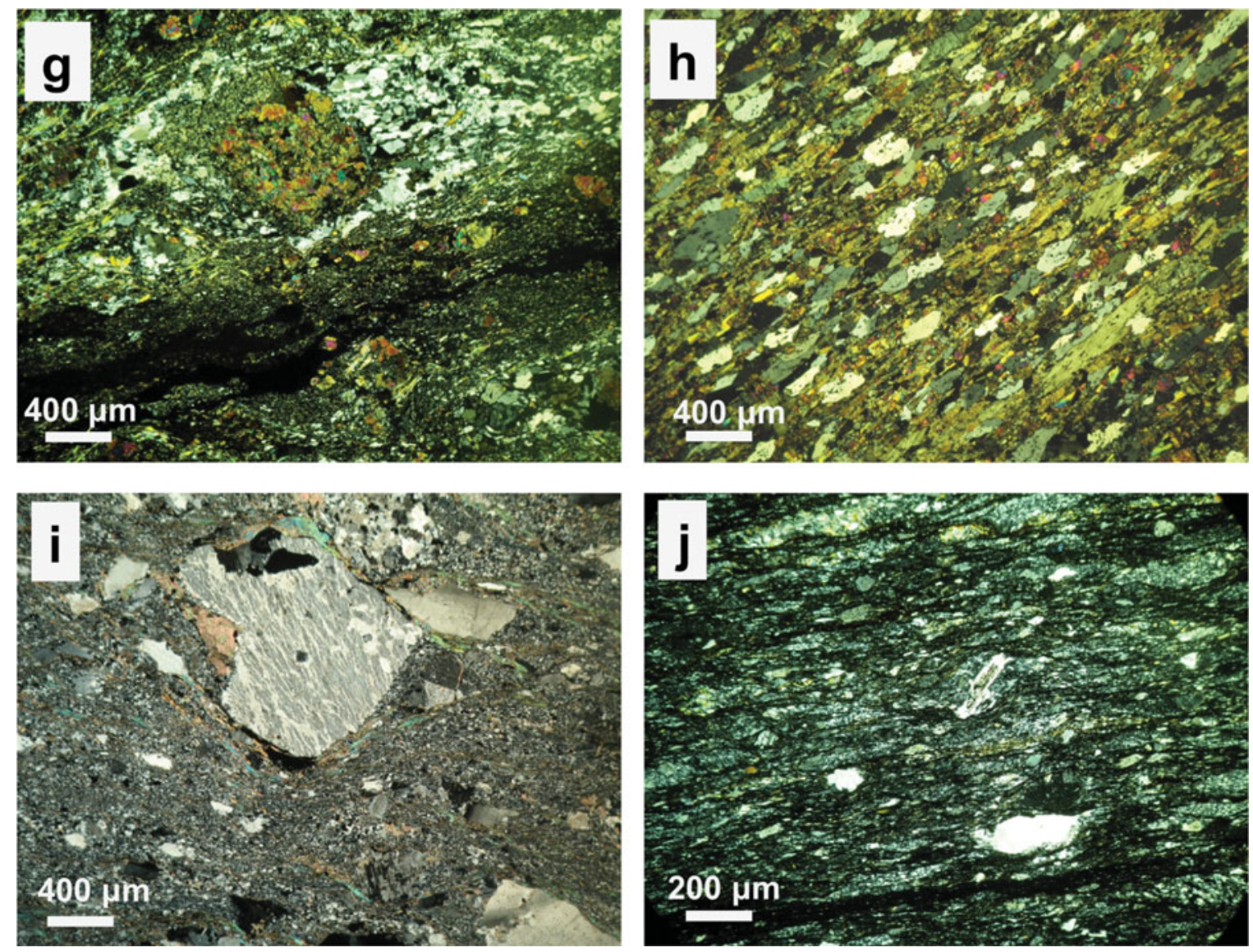

Figure 6. (Continued) (Colour online) (g, h) Epidote-rich metabasite in BKC at Boyac1 (transect 'i'); (i) perthitic orthoclase grain in coarse-grained meta-arkose (transect ' $k$ ') and (j) acidic metavolcanite (transect 'l') in AMC SE of Amasya. Crossed polars.

corrected using the PAP matrix correction. Representative chemical analyses for each detected phase are reported in Tables 4 and 5. For mineral abbreviations, see footnote to Table 1 .

Feldspars are composed only of unzoned pure albite crystals in all the studied rocks (Table 4).

Garnet porphyroblasts show a clear compositional zoning passing from core (almandine $=45-50 \mathrm{~mol} \%$, spessartine $=25-30 \mathrm{~mol} \%$, pyrope $=2-4 \mathrm{~mol} \%$, grossular $=9-25 \mathrm{~mol} \%$ ) to rim (almandine $=57-$ $62 \mathrm{~mol} \%$, spessartine $=12-15 \mathrm{~mol} \%$, pyrope $=4$ $5 \mathrm{~mol} \%$, grossular $=12-22 \mathrm{~mol} \%)($ Table 4$)$. The andradite end-member is variable, varying up to 12 mol $\%$, but it does not show significant changes within a single porphyroblast. The uvarovite end-member is always lower than $1.5 \mathrm{~mol} \%$. Thus, the most considerable chemical zoning within the garnet porphyroblasts is in regards to the almandine and spessartine endmembers, and their variations gradually change from core to rim (Fig. 7).

Micas in the micaschists are classified as a solid solution of aluminoceladonite $\left(\mathrm{KAl}\left(\mathrm{Mg}, \mathrm{Fe}^{2+}\right)\right.$ $\left.\square \mathrm{Si}_{4} \mathrm{O}_{10}(\mathrm{OH})_{2}\right)$ and muscovite $\left(\mathrm{KAl}_{2} \square \mathrm{AlSi}_{3}\right.$ $\mathrm{O}_{10}(\mathrm{OH})_{2}$ ) according to the nomenclature of the micas of Rieder et al. (1998) (Table 4). This phase can be also termed phengite (Deer, Howie \& Zussman, 1992) despite being considered obsolete by the previous authors. $\mathrm{Si}$ is in the range $3.30-3.38$ atoms per 11 oxygens and $\mathrm{Mg}$ no. $(100 * \mathrm{Mg} /(\mathrm{Mg}+\mathrm{Fe}))$ is in the range 52-61. Micas are locally altered into clay minerals.

Chlorite in both the glaucophane-bearing micaschists and metabasite, and in the greenschist metavolcanites is classified as a Type I Mg-chlorite according to Zane \& Weiss (1998); the analysed crystals pertain to the pycnochlorite variety with $\mathrm{Mg}$ no. $=$ 54-65 (Table 4).

Amphibole has quite a different composition (Table 5). According to the nomenclature proposed by the International Mineralogical Association (Hawthorne et al. 2012), the analyses were recalculated according to Locock (2014). The blue amphibole relics in the micaschists point to glaucophane, whereas the alkali amphibole in the metabasite is classified as Fe-glaucophane. In addition, the metabasite includes $\mathrm{Ca}$ and $\mathrm{Na}-\mathrm{Ca}$ amphibole (i.e. winchite, magnesio-hornblende and magnesio- ferric hornblende). According to the nomenclature of Rock \& Leake (1984) and Leake et al. (2004), winchite is classified as barroisite. Octahedral $\mathrm{Al}\left({ }^{\mathrm{VI}} \mathrm{Al}\right)$ is different among these $\mathrm{Na}, \mathrm{Ca}$ and $\mathrm{Na}-\mathrm{Ca}$ amphiboles, as evidenced in Figure 8.

Epidote in the metabasite and in the greenschist metavolcanites is defined as epidote sensu stricto (s.s.). 
Table 4. Chemical analyses of garnets, feldspars, micas and chlorites found in micaschists and metabasite

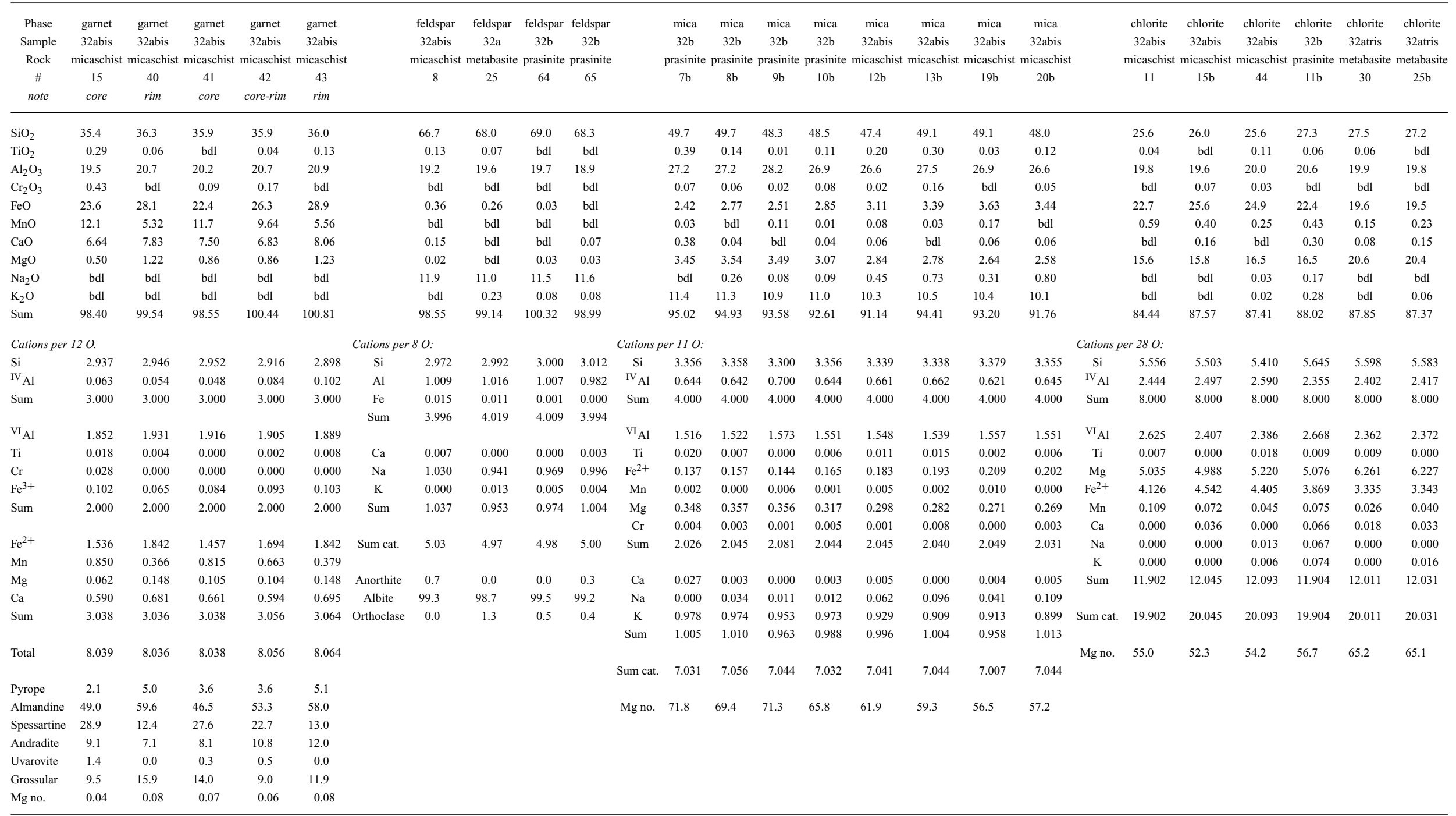

bdl - below detection limit; $\mathrm{Mg}$ no. $-\mathrm{Mg} /\left(\mathrm{Mg}+\mathrm{Fe}^{2+}\right)$; (c) - calculated; Sum cat. - sum cations; end-members in mol\%; na - not analysed. 


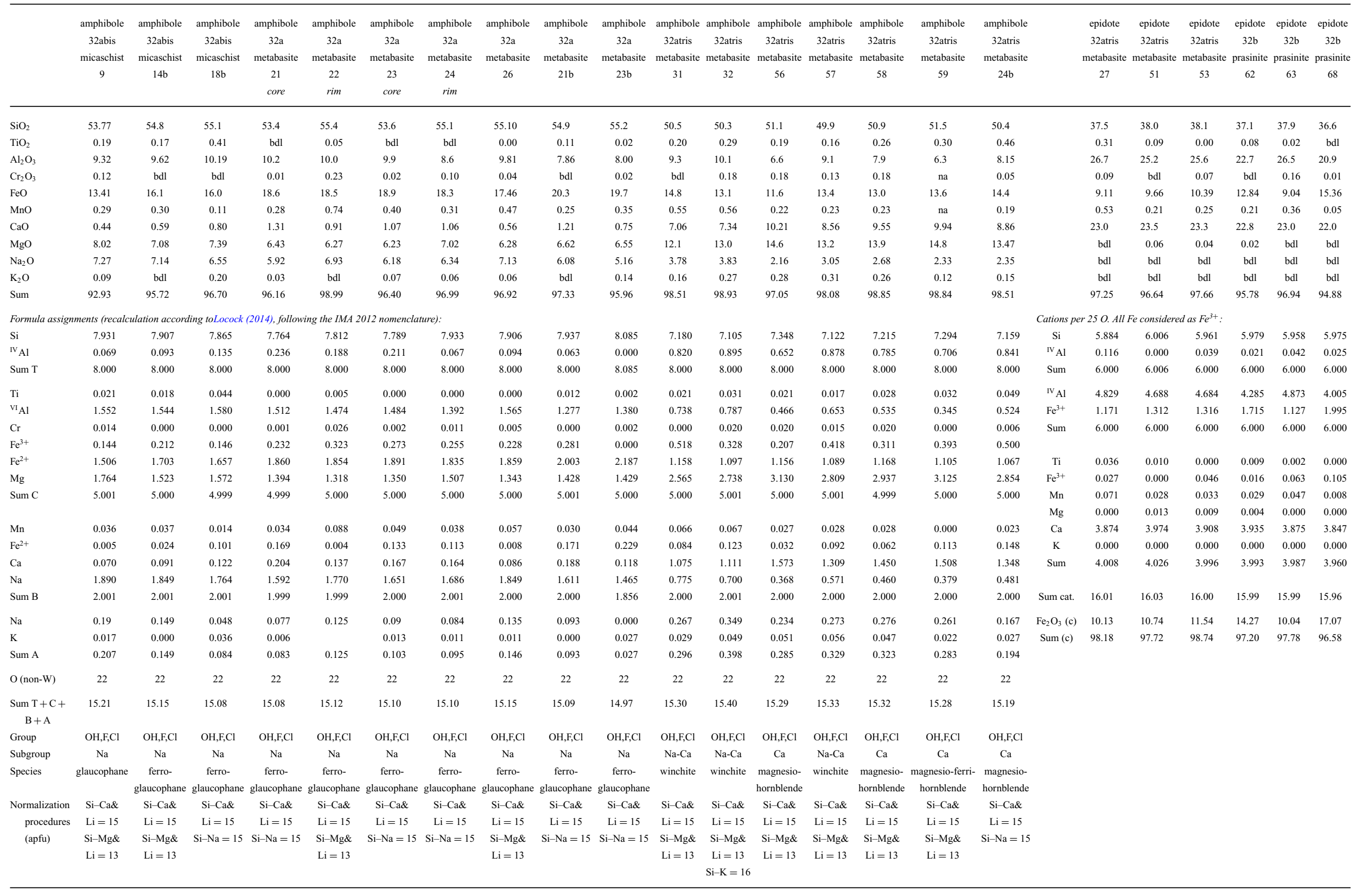

bdl - below detection limit; na - not analysed. 


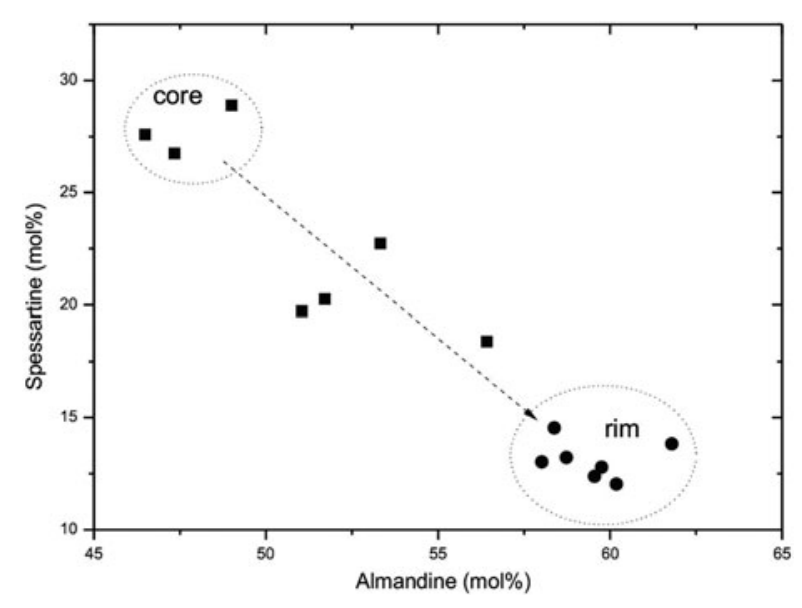

Figure 7. Compositional zoning in the analysed garnets evidenced by almandine $\left(\mathrm{Fe}_{3} \mathrm{Al}_{2} \mathrm{Si}_{3} \mathrm{O}_{12}\right)$ and spessartine $\left(\mathrm{Mn}_{3} \mathrm{Al}_{2} \mathrm{Si}_{3} \mathrm{O}_{12}\right)$ contents.

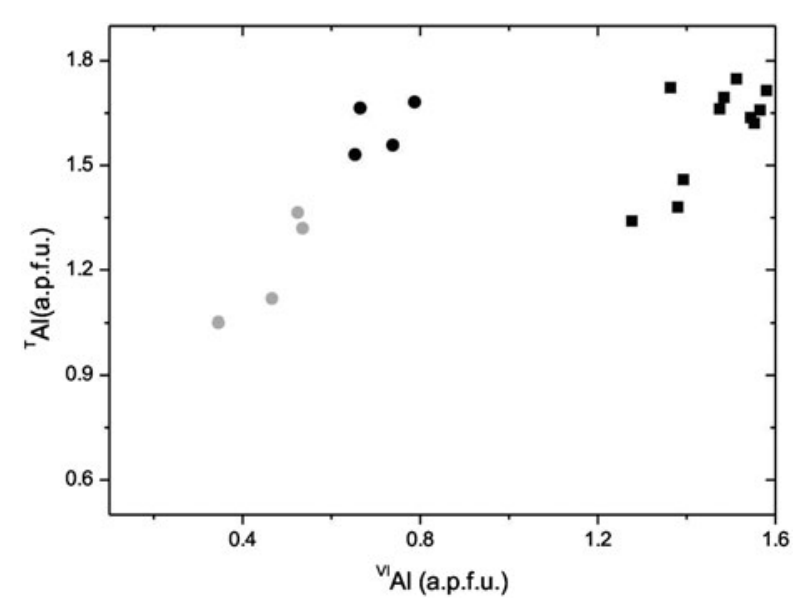

Figure 8. ${ }^{\mathrm{VI}} \mathrm{Al}$ versus total $\mathrm{Al}\left({ }^{\mathrm{T}} \mathrm{Al}\right)$ in sodic-calcic (black circles), calcic (grey circles) and alkali (squares) amphiboles. a.p.f.u. - atoms per formula unit.

Epidote has highly variable $\mathrm{Fe}_{2} \mathrm{O}_{3}$ from 10 to $17 \mathrm{wt} \%$ that is inversely proportional to $\mathrm{Al}_{2} \mathrm{O}_{3}$ from 27 down to $21 \mathrm{wt} \%$ (Table 5).

\section{4.c. Structural data}

4.c.1. BAA and $A M C$

These greenschist-facies metamorphic successions were affected by three deformation events that are named $\mathrm{D}_{1}, \mathrm{D}_{2}$ and $\mathrm{D}_{3}$ (see Fig. $9 \mathrm{a}, \mathrm{b}$ and stereonets for the collected data about $\mathrm{S}_{1}, \mathrm{~S}_{2} ; \mathrm{B}_{1}, \mathrm{~B}_{2}$ and $\mathrm{B}_{3}$ axes and syn- $\mathrm{D}_{1}$ mineralogic lineation (LM) in Fig. 10 for the different areas):

(1) The first event $D_{1}$ produced an intensively penetrative fine-grained foliation $\left(\mathrm{S}_{1}\right)$ defined by $\mathrm{Qtz}+\mathrm{Ser}+\mathrm{Chl}+\mathrm{Cc} \pm \mathrm{Ab}( \pm \mathrm{Tr}-$ Act in the metabasite) + Grf or Hem that is parallel to the lithological alternations $\left(\mathrm{S}_{0}\right.$ ?) and represents the main meso- and microscopic structure of the rocks of both units. In the samples characterized by an augen texture, porphyroclasts display $\sigma$ - and $\delta$-type mantle shapes. $S_{1}$ is locally associated with isoclinal/tight folds as axial plane foliation (Fig. 9a) and often mineral lineations (essentially Qtz and white mica blasts) lie above it. The few collected data about the $B_{1}$ axes of the $D_{1}$ folds in the $A$, $\mathrm{B} 1$ and $\mathrm{C}$ areas show a NW-SE main strike and rarely NE-SW (only in transect 'd' of the B1 area). The mineralogic lineations lying on $S_{1}$ show a wide distribution of strikes (from NNW-SSE to WSW-ENE) and dips: towards the SE (transects ' $a$ ' and ' $b$ ' in area A) or mostly to the NNW (transect ' $k$ ' of area $C$ ), and also to the NW and to the SW (transect ' $c$ ' of area A), to the NE (transects ' $d$ ' and ' $e$ ' in area B1) or dispersed from ENE to SSW (transect ' 1 ' in area C). The few data about the shear structures, obtained through the rare kinematic indicators ( $\sigma$-type porphyroclasts and S-C structures) in both units in transects 'a', 'c', 'd', ' $\mathrm{k}$ ' and ' $\mathrm{l}$ ' give a top-to-the-SE and local top-to-theNE sense of shear.

(2) The $\mathrm{D}_{2}$ event is represented by close to tight folds (Fig. 9b) to which a spaced zonal to rarely discrete crenulation cleavage $\mathrm{C}_{2}$ (defined by the reorientation of oxides + organic matter and the blastesis of Ser $\pm \mathrm{Chl}$ ) is associated. The distribution of the $\mathrm{B}_{2}$ axes of $F_{2}$ shows a mostly NW-SE strike, but locally also around E-W (transect d), NE-SW (transects 'd', 'e', 'l') and NNE-SSW (transect ' $c$ ').

(3) In the field, a local non-metamorphic $\mathrm{D}_{3}$ weak folding event was defined by kink folds whose $\mathrm{B}_{3}$ axes generally show NE-SW strikes in all the transects. However, a few of them are also from N-S to WNWESE or dip to the WNW in the transects ' $h$ ' and ' $d$ ', respectively, of area B1.

Analyses of the calcite twins in the syn-tectonic blasts and post- $\mathrm{D}_{2}$ veins present in the samples generally point to Burkhard's type II twins followed by type I ones. Sometimes, Burkhard's type III twins also occur.

\section{4.c.2. $B K C$}

In these rocks, four deformation events were defined. In particular, glaucophane-bearing micaschists and gneisses, in the Boyac1 and Kertme-Çayan areas (transects ' $\mathrm{i}$ ' and ' $\mathrm{j}$ ' in the $\mathrm{B} 2$ area), are characterized by a coarse-grained $S_{1}$ main foliation that is made up of $\mathrm{Qtz}+\mathrm{Pl} / \mathrm{Ab}+\mathrm{Ms}+\mathrm{Cc} \pm \mathrm{Bt}( \pm \mathrm{Chl})$ that is often underlined by $\mathrm{Ep}+\mathrm{Ttn}+\mathrm{Ox}$ trails. Microscopic observations infer that $\mathrm{Chl}$, replacing $\mathrm{Gln}$ and $\mathrm{Bt}$, developed generally later compared to the other phases due to metamorphic retrocession. There is also the remarkably peculiar presence of syn-tectonic $\left(\right.$ syn- $\left.S_{1}\right)$ Grt and $\mathrm{Ab}$ porphyroblasts along $\mathrm{S}_{1}$ (Fig. 6e). Also, the sub-idiomorphic Gln is generally aligned with $S_{1}$, but it is a relict phase (likely belonging to a HP-LT, pre- $\mathrm{D}_{1}$ event), given that it is frequently stretched/boudinaged with fractures filled by $\mathrm{Chl} \pm$ altered $\mathrm{Bt}$ and are often characterized by $\mathrm{Chl} \pm \mathrm{Bt} \pm \mathrm{Qtz}$ pressure shadows (Fig. 9c, d). In addition, Gln is sometimes characterized by inclusion trails of opaque and fibrous (e.g. Rt) minerals that are perpendicular to the blast boundar- 

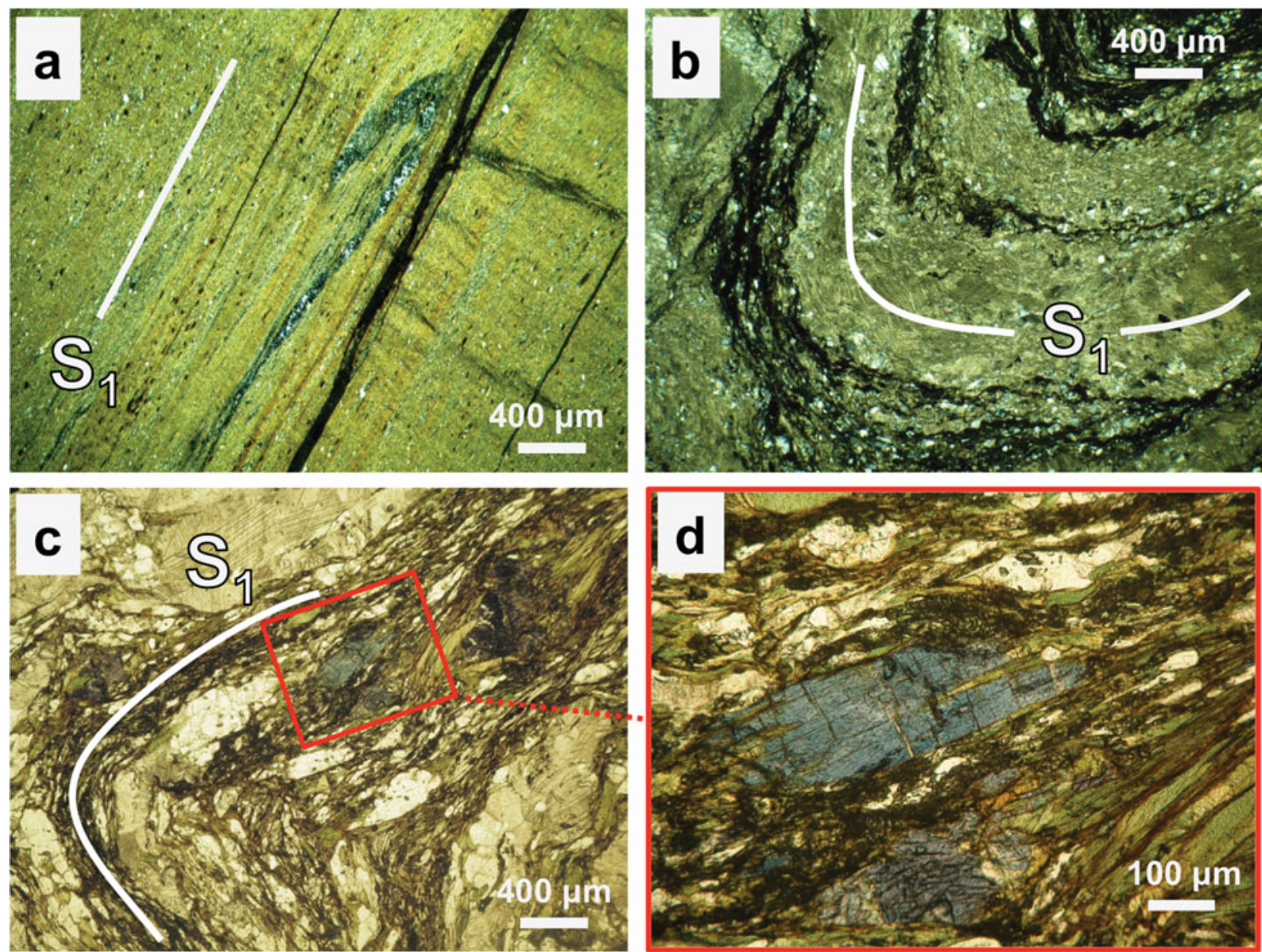

Figure 9. (Colour online) (a) Unrooted $\mathrm{D}_{1}$ isoclinal fold in BAAb phyllite in Akyurt area (transect ' $a$ '), crossed polars. (b) $\mathrm{D}_{2}$ fold in BAAc calcschist in Aydıncık area (transect ' $d$ '), crossed polars. (c) $D_{2}$ fold with relics of blue amphibole that is partially retrogressed in the $S_{1}$ greenschist-facies assemblage in BKC micaschist of the Boyac1 area (transect ' $i$ ') and (d) its magnification, crossed polars.

ies, suggesting the presence of an older foliation that pre-dates the blastesis of the blue amphibole.

The metabasites are characterized by a main foliation $\mathrm{S}_{1}$ made up of aiPl $+\mathrm{Hbl}+\mathrm{Cc} \pm \mathrm{Qtz} \pm \mathrm{Bt} \pm \mathrm{Ms}$ (Fig. 6h) including Gln relics, sometimes characterized by $\mathrm{Hbl}$ corona. These rocks are mostly or completely retrogressed into $\mathrm{Chl}, \mathrm{Ab}$ and Ep-rich greenschist-facies rocks (i.e. 'prasinite' in French, German and Italian literature), sometimes showing a mylonitic fabric (Fig. 6g).

The chemical analyses performed on $\mathrm{Mu}$ in both the micaschists and metabasites reveal its phengitic composition, i.e. in between the aluminoceladonite and muscovite end-members (see Section 4.b).

The mineralogic lineations lying on $\mathrm{S}_{1}(\mathrm{Ab}, \mathrm{Qtz}$, $\mathrm{Mu}, \mathrm{Chl}$ and Gln relics) dip to the WSW and SSE in transect ' $i$ ' and to the NE and SE in transect ' $j$ '. A topto-the-SE sense of shear was locally defined by syn- $\mathrm{S}_{1}$, $\sigma$-type porphyroblasts ( $\mathrm{Ab}$ and $\mathrm{Grt}$ ) in the micaschist and $\mathrm{S}-\mathrm{C}$ structure in the marble.

$\mathrm{S}_{1}$ is deformed by $\mathrm{D}_{2}$ that is represented by close/tight folds associated with $\mathrm{C}_{2}$ zonal crenulation. Later, weak folds $\left(\mathrm{F}_{3}\right)$ were also recognized. Finally, Burkhard's type II and later type I twins were recognized in the marble. 4.c.3. Relationships of the $B A A, A M C$ and $B K C$ with the carbonate cover sequences

As regards the contact of the BAA and AMC with the carbonate cover sequences, it is clearly tectonic or at least tectonized in many places. For example, local metric/decametric cataclastic horizons and tectonic slices are recognizable at the contact between the $A M C$ and the overlying carbonate $\mathrm{j}_{3}-\mathrm{k}_{1}$ successions in transect ' 1 ' of the Amasya area. In particular, the structural independence of the $j_{3}-k_{1}$ carbonate rocks with respect to the underlying and already piled up BAA and $\mathrm{BKC}$ units is shown in the surroundings of transect ' $i$ ' in the Boyac1 area (see Fig. 2c and MTA, 2002, 2010).

\section{4.c.4. $A O M$}

The structural data collected in the IAESZ melange from different sites along the Kizilirmak River in the Kalecik area show that the sampled serpentinite mylonites are made up of a syn-kinematic assemblage of often ferriferous (Fe oxide and hydroxide-rich) calcite fibres at the millimetric scale wrapping around heterometric clasts of serpentinite with locally preserved 


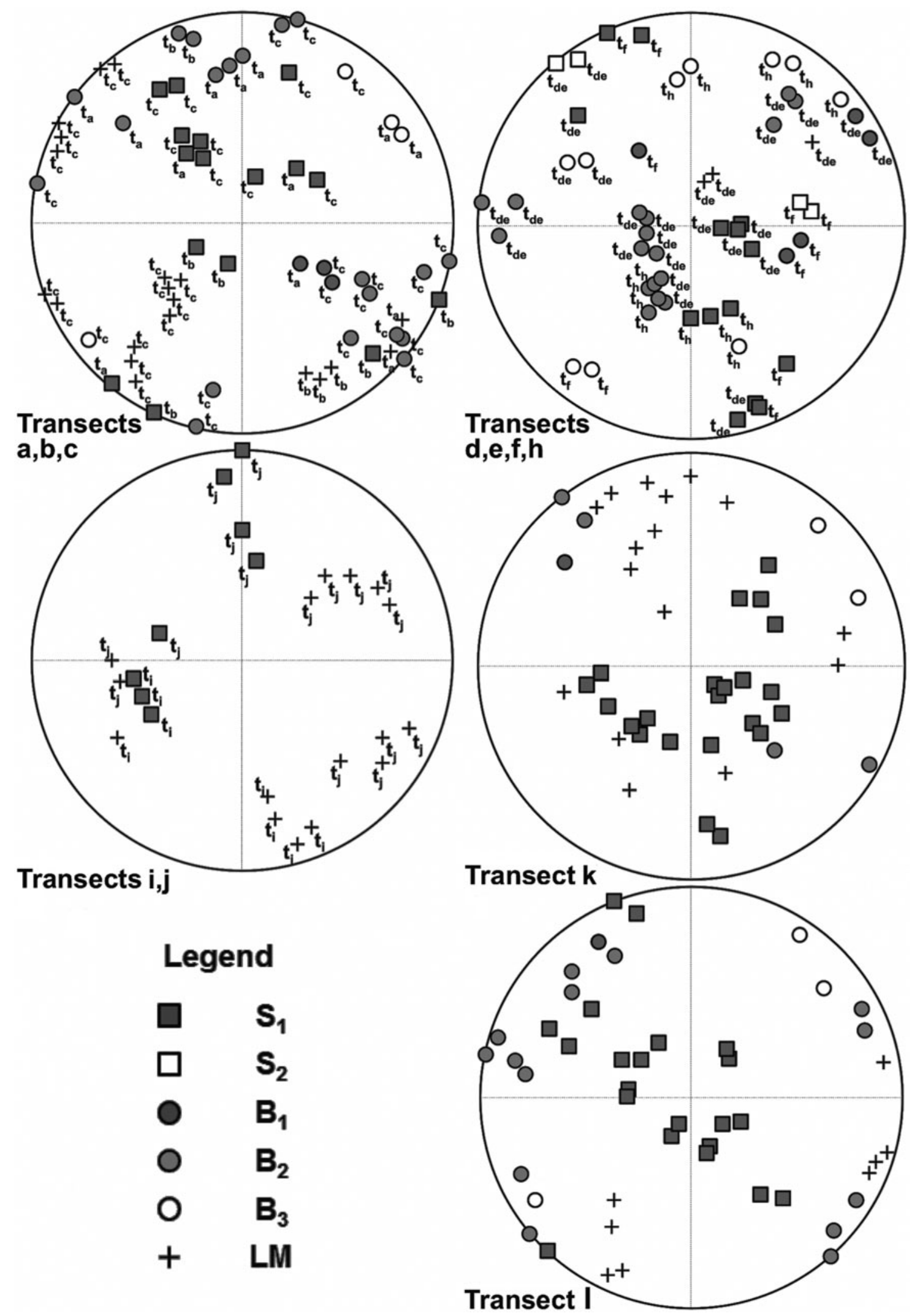

Figure 10. Stereonets, equal area projections, lower hemisphere of the meso-structural data $\left(\mathrm{S}_{0}, \mathrm{~S}_{1}, \mathrm{~S}_{2} ; \mathrm{B}_{1}, \mathrm{~B}_{2}, \mathrm{~B}_{3}\right.$ axes; $\mathrm{LM}-\mathrm{min}$ eralogic lineations lying above $\mathrm{S}_{1}$ ) collected in BAA, BKC and AMC units in the different studied areas: transects ' $a$ ', ' $b$ ' and ' $c$ ' (Akyurth-Bozca-Avciova in area A); transects 'd', 'e', 'f' (Aydincik-Fuadiye and Büyüksogütözü-Kogazcale in area B1) and transect ' $h$ ' (Küre-Cemilbey road in area B2); transects ' $i$ ' and ' $j$ ' (Boyaci and Kertme-Çayan in area B2); transect 'k' (Mathmalar-Kalekoi Valley in area C); transect ' 1 ' (road from Kalekoi Valley to Kayrak in area C). 
mesh structures or sometimes completely amphibolitized/chloritized and of aggregates of iron oxides and hydroxides (Fig. 5j). Locally, micritic to microcrystalline carbonates with marly, lumpy/peloidal-like textures, possibly derived from the micritic matrix of the original ophiolitic breccias, are also present within the calcite foliation. Shear zones, characterized by S-C planes, generally showing a top-to-the-SW or to-the-SE sense (see also Rojay, 2013), are common, but, locally, a top-to-the-NE sense can be defined. The mylonitic foliation is locally deformed by zonal crenulations that are underlined by oxide alignments.

The data concerning the Upper Cretaceous flysch successions cropping out along the road from Çorum to Alaca (transect ' $\mathrm{g}$ ' in B2, Fig. 2c) show that these rocks suffered at least one deformation event. In particular, the metric to decametric close to tight folds, asymmetrical to recumbent in attitude, are characterized by NE-SW-oriented axes and southern vergence (Fig. 51).

The Calpionella-like limestone olistoliths show different fold structures that are represented by open to closed folds, from symmetric (Fig. $5 \mathrm{~m}$ ) to asymmetric in shape. These latter show different vergences in the different outcrops, but generally they point to southern quarters.

The ophiolitic melange tectonically underlies the Sakarya Zone units; nevertheless their geometric relationships are locally reversed in the SE part of the B2 and C areas (e.g. in transect ' 1 ', south of Kayrak village in the Amasya area, Fig. 2d).

\section{Discussion}

Two different Palaeozoic-Triassic successions, made up of sedimentary and metamorphic rocks ('pt' and 's', respectively), were identified below the Mesozoic carbonate platform sediments in the 1:500 000 geological map of Turkey (MTA, 2002). The data obtained from our study improve the stratigraphic, structural and metamorphic knowledge of these two units and, more generally, of the frontal part of the Sakarya Zone in the Ankara-Çankırı, Çorum and Amasya areas.

In particular, both 'pt' and 's' are represented by metamorphic rocks. In this framework, we distinguished three main tectonostratigraphic units (the BAA, BKC and AMC, see Figs 2, 3):

BAA greenschist-facies metamorphic rocks represents most of the 'pt' from the Ankara to Çorum areas and can be divided into three members consisting of basal coarse-grained metasandstone (Member a), passing vertically into alternating phyllite, siltstone and metasandstone with rare metacarbonate layers (Member b) and finally into varicoloured marble and calcschist with phyllitic intercalations (Member c). This latter member was mapped as 's ' in MTA (2002). In the members a and b, the quartzitic metasandstone and feldspathic metagreywackes include rock fragments mostly derived from acidic volcanites and subordinately from metamorphic rocks.
The BKC (mapped as 'ş' in MTA, 2002) was recognized only in the Boyac1-Kertme area (SE of Çorum, along transects ' $i$ ' and ' $j$ ') geometrically below the BAA. It consists of poly-metamorphic rocks such as Gln- and Grt-bearing micaschists, amphibolitic gneisses and metabasite and marbles that experienced a complex metamorphic evolution from HP-LP blueschist- to greenschist-facies conditions. Considering the different lithological features and metamorphic evolutions of the BAA and BKC, we hypothesize that they likely represent the tectonic stacking of two different tectonic units in the study area.

The AMC greenschist-facies metamorphic unit is represented only in the Amasya area (transects ' $\mathrm{k}$ ', ' $l$ ' and ' $m$ ' in the NW part of the Tokat Massif) and can be preliminarily divided in three members: (a) basal metasiliciclastic rocks, (b) intermediate varicoloured phyllitic-calcschist-marble alternations grading upwards into the (c) thick upper member represented by prevalent acidic to intermediate/basic metavolcanites and volcanic metasediments with local phyllitemetacarbonate horizons. The metasandstones of the basal member are lithologically similar to those of the BAA, but they are frequently a meta-arkose characterized by acidic plutonic components. Rare relics of blue amphibole were found in the metavolcanites. Catlos, Huber \& Shin (2013) found in the same AMC successions also metagabbro and metabasalts that are characterized by an E-MORB or a within oceanic plate basalt (WOPB) signature.

The sharp contact of these units with the overlying non-metamorphic Mesozoic ' $\mathrm{t}_{2-3}$ ' or ' $\mathrm{j}_{3}-\mathrm{k}_{1}$ ' carbonate rocks was generally interpreted by the previous authors as the evidence of the unconformity related to the Late Triassic Cimmerian Orogeny (see MTA, 2002, 2010). A Cimmerian age of the tectonometamorphic framework of the BAA is testified to by the intrusion of non-metamorphic, intermediate to basic Late Triassic dykes in the metasiliciclastic rocks (see transects ' $a$ ' and ' $b$ '). These dykes could be considered the feeders of the magmatic sub-marine flows intercalated in the overlying non-metamorphic carbonate succession of transect ' $a$ '. Instead, according to the ${ }^{238} \mathrm{U}-{ }^{206} \mathrm{~Pb}$ radiometric data on zircons and baddeleyite of Catlos, Huber \& Shin (2013), the metamorphism of the AMC rocks seems earlier (200$135 \mathrm{Ma})$. Unfortunately, we have not yet obtained radiometric ages for the metamorphic assemblage of the BKC. Our study also reveals the frequent tectonic independence of the Mesozoic carbonates compared to the underlying metamorphic successions, as suggested by the interposition of cataclastic horizons and tectonic slices (e.g. in the Amasya transect 'l'). In this framework, it is also worth noting that the ' $\mathrm{j}_{3}-$ $\mathrm{k}_{1}$ ' carbonates rest on both the BAA and BKC 'sealing' their tectonic contact in the B2 area (transects ' $\mathrm{i}$ ' and ' $\mathrm{j}$ ').

The collected structural and metamorphic data point out similarities between the blastesis-deformation relationships of the BAA and AMC greenschist-facies 
metamorphic rocks (cf. structural data). These successions display evidence of three superimposed deformation events as $D_{1}, D_{2}$ and $D_{3}$, the first two of which are in the greenschist facies. $D_{1}$ is the main event, producing continuous foliation $S_{1}$ $=\mathrm{Qtz}+\mathrm{Ser}+\mathrm{Chl}+\mathrm{Cc}+\mathrm{Ox}+\mathrm{Grf} / \mathrm{Hem} \pm \mathrm{Ab} \pm \mathrm{Tr}-$ Act that is related to an isoclinal/tight folding which is rarely observable at the meso-scale. $\mathrm{B}_{1}$ axes and $\mathrm{L}_{1}$ mineralogic lineations on $S_{1}$ generally point to the NW and SE quarters. The $\mathrm{D}_{2}$ close to tight folds, which are the most common structures at the meso- and microscales, are characterized by a spaced zonal to rarely discrete $\mathrm{S}_{2}(=\mathrm{Ser}+$ oxides + organic matter $\pm \mathrm{Chl})$ crenulation cleavage. $\mathrm{B}_{2}$ axes are generally co-axial with respect to $\mathrm{B}_{1}$, but locally show a NE-SW (transect ' 1 ' in area C) strike or are concentrated around an $\mathrm{E}-\mathrm{W}$ direction (area B1). A non-metamorphic $\mathrm{D}_{3}$ weak folding, defined by kinks with a NE-SWtrending $\mathrm{B}_{3}$ axes, was also identified in the examined areas.

The $150-300{ }^{\circ} \mathrm{C}$ closure temperature of the metamorphic system, probably occurring during the $\mathrm{D}_{2}-\mathrm{D}_{3}$ events, is given by Burkhard's type II and later type I twins occurring in the $\mathrm{Cc}$ blasts in the calcschist and marble and in the post- $\mathrm{D}_{2}$ calcite veins.

The rare relics of blue amphibole found in the AMC metavolcanites (sample 41a in transect ' 1 ') suggest that this unit locally reached the HP-LT metamorphic conditions (see also Catlos, Huber \& Shin, 2013), but this evidence was mostly hidden due to the strong greenschist-facies metamorphic imprint related to the $\mathrm{D}_{1}$ event.

The metamorphic and structural framework of the $\mathrm{BKC}$ is peculiar compared to the BAA and AMC because the former suffered a more complex metamorphic and deformation history from blueschist to greenschist facies. In particular, these micaschists, amphibolitic gneisses, metabasite and marble are characterized by a coarser main foliation $\left(\mathrm{S}_{1}\right)$ made up of upper greenschist to lower amphibolitic facies minerals. Specifically, in the metasiliciclastic rocks $\mathrm{S}_{1}=\mathrm{Qtz}+\mathrm{Ab}+\mathrm{Ms}+\mathrm{Bt}+\mathrm{Grt} \pm \mathrm{Chl}$, while in the metabasite $\mathrm{S}_{1}=\mathrm{Hbl}+\mathrm{Ab} / \mathrm{Pl}+\mathrm{Bt} \pm \mathrm{Chl}$ or $\mathrm{Ab}+\mathrm{Qtz}+\mathrm{Chl}+\mathrm{Cc}+\mathrm{Ms}+\mathrm{Ep}$. The mineralogic lineations on $\mathrm{S}_{1}$ strike WSW-ENE or dip to the SE quarter. An overall late $S_{1}$ chloritization also occurs in both rocks, previously the $\mathrm{D}_{2}$ folding event. Blue amphiboles (i.e. glaucophane in the micaschists, Feglaucophane and crossite in the metabasites) are pre$\mathrm{S}_{1}$ relict minerals, pre-dating the regional metamorphism events and showing the existence of a pre- $\mathrm{D}_{1} \mathrm{HP}-$ LT event. The presence of barroisite in the Hbl-bearing metabasite infers that the former mineral is related to decompressional re-equilibration of the previous blue amphibole at regional metamorphic conditions of $P$ $=4-5 \mathrm{kbar}$ and $T \cong 350^{\circ} \mathrm{C}$ or $P=5-7 \mathrm{kbar}$ and $T$ $\cong 450^{\circ} \mathrm{C}$ (Ernst, 1979). It is also worth noting that the presence of foliation relics (made up of opaque and fibrous minerals) within Gln porphyroclasts of the micaschist possibly points to an older metamorphic event that occurred before the growth of the blue amphibole.

The evidence of HP-LT metamorphism is well known in the crystalline basement units of the western Anatolides (e.g. Menderes Massif, Lycian Nappe, Tavşanlı Zone, Afyon Zone) and Pontides that points to a diachronous subduction event from the Cretaceous, to the north, to the Eocene, to the south (Okay \& Kelley, 1994; Sherlock et al. 1999; Rimmelé et al. 2003; Çetinkaplan et al. 2008; Catlos, Huber \& Shin, 2013; Pourteau et al. 2013, 2015; Aygül et al. 2015; Okay \& Nikishin, 2015 and references therein).

Blueschist-facies minerals were found in the Central Pontides within the crystalline rocks of the Sakarya Zone of the Karg1 Massif (R. H. Eren, unpub. Ph.D. thesis, Istanbul Technical Univ., 1979; O. Tüysüz, unpub. Ph.D. thesis, Istanbul Üniv., 1985; Okay et al. 2006; Aygül et al. 2016) to the NNW of the studied Ankara-Çankırı area (A in Fig. 1). In particular, the $\mathrm{BKC}$ blue amphibole-bearing micaschist and metabasite below the BAA low-grade metamorphic siliciclastic rocks in the B2 area (transects ' $\mathrm{i}$ ' and ' $\mathrm{j}$ ') and, possibly, in the ENE surroundings of Çorum, resembles the tectonic superposition of the greenschistfacies, phyllitic-metabasitic-marble Çangaldağ Complex above the HP-LT Domuzdağ Complex in the frontal part of the Central Pontides (Okay et al. 2006).

Similarly to the BKC, the Domuzdag Complex consists of blueschist, garnet-bearing chloritoidglaucophane (mostly Fe-glaucophane)-quartzmicaschist, glaucophane metabasite and minor marble and meta-chert, and irregular tectonic lenses of serpentinite. These rocks are more or less retrogressed to greenschist facies (i.e. retrogression of the metabasite into $\mathrm{Ab}-\mathrm{Ep}-\mathrm{Chl}$ gneisses with common calcic amphiboles). Moreover, the Domuzdağ HP-LT Complex locally includes omphacite + glaucophane eclogitic bands, but these haven't been found until now in the BKC. The chemical composition of the garnets within the micaschists of the Çangaldağ Complex (almandine-spessartine-grossular garnets with less than $6 \%$ pyrope with significant reverse zoning between $\mathrm{Mn}$ and $\mathrm{Fe}$ ) strongly recalls the studied BKC garnets (cf. Section 4.b). Finally, the chemical analyses performed by Okay et al. (2006) and Aygül et al. (2016) in the HP-LT rocks of the Domuzdağ Complex show a phengitic composition for $\mathrm{Mu}$ that is similar to that found in the BKC micaschists and metabasites, but with a higher content of $\mathrm{Si}$ and, sometimes, also of $\mathrm{Fe}$ and $\mathrm{Mg}$.

Okay et al. (2006) and Aygül et al. (2016) attributed the whole Domuzdağ Complex to a Tethyan oceanic subduction-accretion complex since the geochemical features of its metabasites have a MORB-type signature (Ustaömer \& Robertson, 1997, 1999, 2010). A Middle Cretaceous age (Albian, $105 \pm 5 \mathrm{Ma} \mathrm{Ar}-\mathrm{Ar}$ and $\mathrm{Rb}-\mathrm{Sr}$ radiometric age of eclogites and chloritoid micaschists in Okay et al. 2006; 114-92 Ma in Aygül et al. 2016; Okay et al. 2013) was defined for 
the HP-LT event of the Domuzdağ Complex rocks that is characterized by $P=17 \mathrm{kbar}$ and $T=490^{\circ} \mathrm{C}$ peak conditions. The same authors also suggested a Late Cretaceous-Tertiary age for the greenschistfacies overprint.

The Çangaldağ Complex shows close lithostratigraphic similarities with the BAA and, particularly, with the AMC, both characterized by a greenschistfacies metamorphic framework (cf. Okay et al. 2006). In fact, the Çangaldağ Complex is made up of a basal part constituted by prevalent metasiliciclastic rocks that pass upwards to a thick metavolcanic succession with minor carbonate and phyllite horizons. The protoliths of the metavolcanic succession are mainly pyroclastic and epiclastic rocks with minor dykes, lava flows and pillow lavas. The geochemistry studies performed by Ustaömer \& Robertson (1999) suggested basaltic andesite, andesite and rhyodacite protoliths for them and an IAT signature. In particular, the same authors attributed these metavolcanites to a PermianTriassic intra-oceanic magmatic arc related to the Cimmerian Orogeny. Moreover, it should be underlined that the Çangaldag Complex suffered a low-grade regional metamorphism in the greenschist facies to local HP-LT metamorphic conditions, during latest Triassic time (205-203 $\mathrm{Ma} \mathrm{Ar}-\mathrm{Ar}$ radiometric age in the Nilüfer Formation in Okay, Monod \& Monié, 2002; Okay et al. 2006). This is in agreement with the, even if rare, presence of blue amphibole in the studied corresponding AMC successions of the Amasya area.

According to the above correlations, the distinguished BAA, BKC and $\mathrm{AMC}$, in the frontal part of the Sakarya Zone from Ankara to Amasya, constitute a very complex tectonic stack of units that suffered different orogenic events and also different burial conditions. The Cimmerian event produced the metamorphic framework of the BAA in Late Triassic time and of the AMC, even if in more recent times (Jurassic - Early Cretaceous in Catlos, Huber \& Shin, 2013). So, both units belong to the so-called Palaeotethyan Karakaya Complex. Instead, the complex metamorphic evolution of the BKC can be related to the Middle Cretaceous to Tertiary Alpine (Neotethyan) events (cf. Okay et al. 2006; Aygül et al. 2016). So the three units testify to a practically continuous accretion of oceanic portions and growth of the Sakarya front since Late Triassic to Tertiary times, in agreement with Okay et al. (2006) and Catlos, Huber \& Shin (2013).

According to this study and regional correlations, the BAA successions, together with their MesozoicTertiary carbonate cover sequences, tectonically overlie the AOM in the western areas (e.g. in areas A and B1). But, the BAA (Karakaya Complex) overthrusts the HP-LT BKC (Neo-Alpine Complex in the B2 area). Despite the lack of data about the lower part of the Sakarya Zone in the latter area where contact with the ophiolitic melange is not exposed, it is obvious that the BKC tectonically pinches out below the BAA towards the west. Additionally, we still have no data to define the relationships between the $\mathrm{BKC}$ and the AMC, because of the lack of outcrops in the intermediate areas, i.e. the SW of Amasya.

The data from the B2 area also allow us to speculate about the age of the building up of such a complex stack of units. First, the tectonic superposition of the BAA (Karakaya Complex) above the BKC likely happened after the main metamorphic imprint (Alpine) stage of the latter unit. So, taking into consideration the radiometric data of the metamorphism in the Domuzdağ Complex (105 Ma in Okay et al. 2006; Aygül et al. 2016), we suggest a Late Paleocene - Early Eocene age for this overthrust, i.e. during the collisional event (cf. Okay, 2008). During these events, also at least part of the Mesozoic carbonate cover sequences detached from their Cimmerian metamorphic base (i.e. BAA and $\mathrm{AMC}$ ) and thrust above the already piled units (e.g. BAA and BKC in the B1 area).

Moreover, the data collected for the AOM in the $\mathrm{A}$ and $\mathrm{B} 1$ areas show that this unit tectonically underlies the Sakarya Zone BAA. The AOM includes shear zones with a top-to-the-SW/SE or, locally, topto-the-NE sense. We suggest that the vergences to the southern quarters are referable to the Late Cretaceous under-thrusting of the ophiolitic melange below the Sakarya Zone margin, whereas the top-tothe-NE sense of shear events can be related to synto post-collisional back-thrusting (see also Robertson et al. 2004, 2014). Also the SE-vergent folding structures recognized in the Cretaceous Flysch and their tectonic slices in the AOM can be likely associated with the Late Cretaceous growth and deformation of the melange itself. Instead, the structural relationships between the AMC and the AOM in the southern $\mathrm{C}$ area (Amasya) appear to be different from place to place. For example, along transect ' $\mathrm{k}$ ' (in the surroundings of Mahmatlar village) and in the Amasya area, the AMC thrusts onto the AOM; however, at the southern end of transect ' 1 ' their structural relationships are reversed. It is assumed that this peculiar situation can be related to the activity of the Alpine syn- and latecollisional back-thrusting of the AOM melange onto the frontal units of the Sakarya Zone (cf. Robertson et al. 2004, 2014), or to the local activity of strike-slip (transpressive) tectonics, due to the irregular shape of the Anatolide margin (e.g. the Kirşehir indenter). This shortening could also produce variation in the axial strike of the $\mathrm{D}_{2}$ folds within the Sakarya units in the different areas (e.g. in the B1 area). It is also worth noting that the ophiolitic melange tectonically includes, in addition to the coeval Cretaceous trench-fore-arc, flysch-like, deposits, shallow-water carbonate olistoliths that likely slid from the frontal part of the Sakarya Zone or from subducted sea mounts (cf. Rojay, 2013). Finally, in the A area, the AOM tectonically lies above Cretaceous-Paleocene clastic trench successions that, in their turn, overthrust the SE Eocene clastic and carbonate rocks that unconformably overlie the CACC. This suggests at least an Eocene age for the tectonic welding of the AOM with the CACC. 
The data in the Ankara-Çankırı, Çorum and Amasya areas reveal a very complex structural evolution for the frontal part of the Sakarya Zone during the Mesozoic-Tertiary, N-directed subduction of the Tethyan Realm (see also Okay et al. 2006; Catlos, Huber \& Shin, 2013; Topuz et al. 2013; Robertson et al. 2014; Aygül et al. 2015, 2016 and references therein). According to regional correlations made in this study, the BAA and AMC can be interpreted as oceanic units belonging to the Karakaya Complex (i.e. the Çangaldağ Complex of the Central Pontides) that suffered the Cimmerian subduction-accretion processes in Late Triassic to Jurassic-Early Cretaceous times. Therefore, these units represented in that time the southern edge of the Sakarya continent (cf. Okay et al. 2006). Instead, the BKC micaschists and metabasites are the analogues to the Domuzdag Complex that is interpreted as a part of the oceanic Neotethyan Realm by Okay et al. (2006) and Aygül et al. (2016). The HP-LT event of the Domuzdag Complex is radiometrically constrained at $c .105 \mathrm{Ma}$, which evidences a Middle Cretaceous active subduction in the northern sector of the Neotethys and the accretion of this Alpine complex to the Cimmerian Sakarya Terrane (Carakaya Complex). This can be considered one of the oldest Alpine events due to the closure of the Neotethys in the whole Alpine orogenic system. Most of the AOM was also produced during these oceanic Middle to Late Cretaceous subduction processes (Göncüoğlu, 2010; Rojay, 2013). In addition, a portion of the rocks within the AOM experienced Alpine HP-LT metamorphism, as evidenced by blue amphiboles found in the ophiolitic breccias sampled at the top of the melange along transect ' $h$ ' in the B2 area. The southward migration of the accretionary processes is testified to by the tectonic incorporation of the trench turbiditic deposits of Middle-Late Cretaceous age in the AOM subduction complexes (see transects ' $d$ ' and ' $\mathrm{g}$ ') during the consumption of the oceanic realm.

According to Okay et al. (2006), the end of subduction processes at the front of the Sakarya Zone and the following exhumation of the BKC rocks occurred in Late Cretaceous time when the regional metamorphism events imprinted this HP-LT unit. In particular, the same authors constrained the exhumation of the Domuzdağ Complex of the Central Pontides to a fore-arc convergent subduction system during Senonian times, considering the underlying Turonian-Coniacian age of the foreland sediments (Kirazbaşi Fm) and the unconformable contact with the overlying uppermost Santonian - lowermost Campanian pelagic limestone cover. In the study area, the exhumation event is testified to by the retrogression of the HP-LT minerals (likely associated with a pre- $\mathrm{D}_{1}$ deformation-metamorphic event) into the dominant amphibolite/greenschist-facies mineral assemblages during the $D_{1}$ folding phase. In particular, glaucophane and crossite in the rocks within the BKC were transformed into barroisite and hornblende, and finally into chlorite during the late stages of $\mathrm{D}_{1}$. Dur- ing this time, the BKC was tectonically sandwiched between the Cimmerian BAA and the AOM that are at the top and at the bottom, respectively, of the tectonic pile of nappes in the A, B1 and B2 studied areas (cf. Okay et al. 2006). Okay et al. (2006) proposed that exhumation of the Domuzdag Complex was triggered by the subduction of the Karg1 microcontinent in front of the accretionary prism.

Afterwards, the remaining part of the Tethys Ocean subducted at least until Late Paleocene time when the Kırşehir Massif began to collide with the complex Sakarya stack with the interposition of the AOM (i.e. IAES). The collected geological data point to an overthrust of the Sakarya Zone units above the AOM of at least $70 \mathrm{~km}$. Final shortenings of the tectonic pile occurred also during Early-Middle Eocene times. During these syn-/late-collisional events, the AOM with its Cretaceous-Paleocene trench deposits thrust onto the Eocene clastic-carbonate cover of the CACC in area A. Moreover, the Sakarya front was partly rearranged through the local detachment of the Mesozoic carbonate cover sequences of the BAA and AMC and their sliding above the already piled units (e.g. BAA on $\mathrm{BKC}$ in $\mathrm{B} 2$ area), and through northward obduction or back-thrusting of the AOM onto the Karakaya Complex (AMC) in the frontal part of the Sakarya Zone in the $\mathrm{B} 2$ and $\mathrm{C}$ areas (see also Robertson et al. 2014). Finally, the role of the Neogene strike-slip tectonics in the final deformation of the studied unit at a local scale cannot be excluded.

Therefore, according to our study and in agreement with Okay et al. (2006), Catlos, Huber \& Shin (2013) and Aygül et al. (2016), we think that the complex tectonic stack of oceanic units present from the Ankara to Amasya areas (e.g. the BAA and AMC Karakaya Units, HP-LT BKC and AOM) in the southern part of the Pontides can be related to a single and prograding subduction-accretion system in front of the Laurasian margin that was active more or less in continuity from Late Triassic to Eocene times instead of the welding of two distinct (Cimmerian v. Alpine) orogenic chains. In this framework, the Cimmerian and Alpine orogenic events can be interpreted as the two main accretion stages of the Laurasian margin. The collisional stage of this long-lived subduction-accretion system occurred only since Late Paleocene time when the Pontide and Anatolide (e.g. CACC) continental masses came into contact with the interposition of the IAES.

\section{Final considerations}

The present data and their interpretations allow us to propose the following conclusions:

(1) Within the Sakarya Zone successions, previously mapped as sedimentary ' $p t$ ' and metamorphic 's successions of Palaeozoic-Triassic age in MTA (2002), we distinguished for the first time three main tectonostratigraphic metamorphic units, i.e. the BAA (in the $\mathrm{A}, \mathrm{B} 1$ and $\mathrm{B} 2$ areas), BKC (only in the B2 area) and $\mathrm{AMC}$ (in the $\mathrm{C}$ area). The BAA and AMC underlie 
the Mesozoic carbonate cover sequences (e.g. $\mathrm{t}_{2-3}, \mathrm{j}_{3}-$ $\mathrm{k}_{1}$ ) that often show tectonic detachment and slicing. In particular:

(a) The BAA includes basal metasiliciclastic rocks (e.g. lithic-feldspathic greywackes) that pass upwards to calcschists, marble and varicoloured phyllite alternations. A Cimmerian age of their greenschistfacies tectono-metamorphic framework is testified to by the intrusion of non-metamorphosed Late Triassic intermediate-basic dykes.

(b) The AMC is made up of basal feldsparrich meta-arkose and meta-pelites passing upwards to carbonate-phyllitic alternations, and then to a thick succession of prevalent acidic to intermediatebasic metavolcanites and volcanic-rich metasediments. Catlos, Huber \& Shin (2013) defined a Cimmerian age for the tectono-metamorphic deformation events of this unit too, even if younger (Jurassic - Early Cretaceous) with respect to that of the BAA. Moreover, the finding of rare glaucophane relics testifies to the local attainment of HP-LT metamorphic conditions.

(c) The BKC consists of poly-metamorphic garnetbearing micaschist, amphibolitic gneiss, metabasite and marble that are characterized by well-preserved relics of blue amphibole (Fe-glaucophane and crossite in the metabasite, glaucophane in the micaschists) and by a strong low-amphibolite- to greenschist-facies retrogression.

(b) The presence of the peculiar HP-LT BKC unit below the greenschist BAA in the $\mathrm{B} 2$ area resembles the tectonic superposition of two similar units (i.e. the Cimmerian Çangaldağ Complex and the Alpine Domuzdağ Complex, respectively, in Okay et al. 2006 and Aygül et al. 2016) present in the frontal part of the Central Pontides.

(c) The ophiolitic melange generally shows a 'blockin-matrix' fabric made up of heterometric serpentinite breccia with clasts up to boulders of more or less brecciated serpentinite and serpentinized peridotite in a serpentinite granular to often finely sheared, foliated (i.e. 'scaly' texture) matrix. From place to place, it includes also olistoliths and slices of the oceanic succession (e.g. serpentinite with microgabbro dykes; Calpionella-like limestones sometimes with basal cherts and basalts; pillow basalts and cherts including sedimentary breccias; manganesiferous cherts). The melange body is often characterized by shear zones displaying a southern, but often also a top-to-the-NE sense of shear. The melange tectonically underlies the Sakarya Zone successions, but their geometrical relationships are locally reversed (e.g. SE of Amasya). These data can be interpreted as the effect of backthrusting and transpression that occurred during the Tertiary syn- to late-collisional shortening events of the accretionary prism.

(d) The collected data show that the frontal part of the Sakarya Zone between Ankara and Amasya (central-eastern Pontides) consists of a complex tectonic stack of different units that likely belong to different oceanic palaeogeographic domains and oro- genic events (Cimmerian v. Alpine orogenies). This tectonic building can be related to a single, prograding and long-lived subduction-accretion system in front of Laurasia that was active from Late Triassic to Paleocene/Eocene times when the collision between the Pontide and Anatolide (e.g. CACC) continental masses took place with the interposition of the IAES.

Acknowledgements. We are grateful to the referees (Prof. F. Meneghini of Pisa University and an anonymous referee) for their comments and criticism that significantly improved the original version of this manuscript. The research was performed through funds from the Italian Ministry of University and Research - PRIN 2010-11 projects (coordinator Prof. E. Pandeli) and the University of Florence.

\section{References}

Aygül, M., Okay, A. I., Oberhänsli, R., Schmidt, A. \& Sudo, M. 2015. Late Cretaceous infant intra-oceanic arc volcanism, the Central Pontides, Turkey: petrogenetic and tectonic implications. Journal of Asian Earth Sciences 111, 312-27.

Aygül, M., OKAY, A. I., Oberhänsli, R. \& Sudo, M. 2016. Pre-collisional accretionary growth of the southern Laurasian margin, Central Pontides, Turkey. Tectonophysics 671, 218-34.

Bortolotti, V., Chiari, M., GöncüOglu, M. C., Marcucci, M., Principi, G., Tekin, U. K., Saccani, E. \& TASSINARI, R. 2013. Age and geochemistry of basalt-chert associations in the ophiolites of the IzmirAnkara mélange east of Ankara, Turkey: preliminary data. Ofioliti 38 (2), 157-73.

Bortolotti, V., Chiari, M. \& Pandeli, E. 2016. Italian contribution to the studies of Anatolian ophiolites. In The Contribution of Italian Scientists to the Geology of Turkey (eds S. Agostini, P. Manetti \& M. Lustrino). Acta Vulcanologica 26/27 (1-2), 89-98.

Catlos, E. J., Huber, K. \& Shin, T. A. 2013. Geochemistry and geochronology of meta-igneous rocks from the Tokat Massif, north-central Turkey: implications for Tethyan reconstructions. International Journal of Earth Sciences 102 (8), 2175-99.

Çelik, Ö. F., Delaloyle, M. F. \& Feraud, G. 2006. Precise $40 \mathrm{Ar}-39 \mathrm{Ar}$ ages from the metamorphic sole rocks of the Tauride Belt Ophiolites, southern Turkey: implications for the rapid cooling history. Geological Magazine 143, 213-27.

Çetinkaplan, M., Candan, O., Oberhänsli, R. \& Bousquet, R. 2008. Pressure temperature evolution of lawsonite eclogite in Sivrihisar; Tavşanlı Zone Turkey. Lithos 104, 12-32.

Deer, W. A., Howie, R. A. \& Zussman, J. 1992. An Introduction to the Rock-Forming Minerals. London: Longman, $696 \mathrm{pp}$.

ERnST, W. G. 1979. Coexisting sodic and calcic amphiboles from high-pressure metamorphic belts and the stability of barroisitic amphibole. Mineralogical Magazine 43, 269-78.

GENÇ, Ş. C. \& TüYsüZ, O. 2010. Tectonic setting of the Jurassic bimodal magmatism in the Sakarya Zone (Central and Western Pontides), Northern Turkey: a geochemical and isotopic approach. Lithos 118, 95-111.

GöncüOĞLU, M. C. 2010. Introduction to the Geology of Turkey: Geodynamic Evolution of the Pre-Alpine and Alpine Terranes. Issue 5 of Monography series, Türkiye 
Maden Tetkik ve Arama Genel Müdürlüğü. General Directorate of Mineral Research and Exploration, 2010, $66 \mathrm{pp}$.

GöncÜOĞLU, M. C., Dirik, K. \& Kozlu, H. 1997. General characteristics of pre-Alpine and Alpine terranes in Turkey: explanatory notes to the terrane map of Turkey. Annales Geologique de Pays Hellenique 37, 515-36.

GöncüoĞLu, M. C., GöncüOglu, Y., Kozlu, H. \& Kozur, H. 2004. Geological evolution of the Taurides during the Infra-Cambrian to Carboniferous period: a Gondwanan perspective based on new biostratigraphic findings. Geol Carphatica 55/6, 433-47.

GöncüoĞlu, M. C., Marroni, M., Pandolfi, L., Ellero, A., Ottria, G., Catanzariti, R., Tekin, U. K. \& Sayit, K. 2014. The Arkot Dağ Mélange in Araç area, central Turkey: evidence of its origin within the geodynamic evolution of the Intra-Pontide suture zone. Journal of Asian Earth Sciences 85, 117-39.

Hawthorne, F. C., Oberti, R., Harlow, G. E., Maresch, W. V., Martin, R. F., Schumacher, J. C. \& Welch, M. D. 2012. Nomenclature of the amphibole supergroup. American Mineralogist 97, 2031-48.

Leake，B. E.，Woolley，A. R., Birch，W. D., Burke, E. A. J., Ferraris, G., Grice, J. D., Hawthorne, F. C., Kisch, H. J., Krivovichev, V. G., Schumacher, J. C., Stephenson, N. C. N. \& Whittaker, E. J. W. 2004. Nomenclature of amphiboles: additions and revisions to the International Mineralogical Association's amphibole nomenclature. European Journal of Mineralogy 16, 191-6.

LococK, A. J. 2014. An Excel spreadsheet to classify chemical analyses of amphiboles following the IMA 2012 recommendations. Computer \& Geosciences 62, 1-11.

Marroni, M., Frassi, C., GöncüoĞlu, M. C., Di Vincenzo, G., Pandolfi, L., Rebay, G., Ellero, A. \& OttriA, G. 2014. Late Jurassic amphibolite facies metamorphism in the Intra-Pontide Suture Zone (Turkey): an eastward extension of the Vardar Ocean from the Balkans into Anatolia? Journal of the Geological Society, London 171, 605-8.

MTA. 2002. 1:500.000 Scale Geological Map of Turkey, Sheet Sinop. Turkish Geological Research Department of Mineral Research and Exploration General Directorate. Ankara: MTA.

MTA. 2010. Geological Map of the Çankiri, H30 Quadrangle at 1:100.000 Scale. Turkish Geological Research Department of Mineral Research and Exploration General Directorate. Ankara: MTA.

Oberhänsli, R., Candan, O., Dora, O. Ö. \& Dürr, S. T. 1997. Eclogites within the Menderes Massif/western Turkey. Lithos 41, 135-50.

Oberhänsli, R., CANDAN, O. \& Wilke, F. 2010. Geochronological evidence of Pan-African eclogites from the Central Menderes Massif, Turkey. Turkish Journal of Earth Sciences 19, 2010, 431-47.

Oberhänsli, R., Monié, P., Candan, O., Warkus, F. C., PARTZSCH, J. H. \& DorA, O. Ö. 1998. The age of bluesschist metamorphism in the Mesozoic cover series of the Menderes Massif. Schweizerische Mineralogische und Petrographische Mitteilungen 78, 309-16.

OKaY, A. I. 2008. Geology of Turkey: a synopsis. Anschnitt 21, 19-42.

OKAY, A. I. 2011. Tavşanlı Zone: the northern subducted margin of the Anatolide-Tauride Block. Bulletin of the Mineral Research and Exploration 142, 191-221.

OKaY, A. I. \& GöNCÜOĞLU, M. C. 2004. Karakaya Complex: a review of data and concepts: Turkish Journal of Earth Sciences 13, 77-95.
Okay, A. I., Harris, N. B. \& Kelley, S. P. 1998. Exhumation of blueschists along a Tethyan suture in northwest Turkey. Tectonophysics 285, 275-99.

OKaY, A. I. \& Kelley, S. P. 1994. Tectonic setting, petrology and geochronology of jadeite + glaucophane and chloritoid + glaucophane schists from northwest Turkey. Journal of Metamorphic Geology 12, 455-66.

OKaY, A. I., Monod, O. \& MoniÉ, P. 2002. Triassic blueschists and eclogites from northwest Turkey: vestiges of the Paleo-Tethyan subduction. Lithos 64, 155-78.

OKAY, A. I. \& NiKishin, A. M. 2015. Tectonic evolution of the southern margin of Laurasia in the Black Sea region. International Geology Review 2015, 1-26.

OKaY, A. I., SATIR, M., TÜYSÜZ, O., AKYÜZ, S. \& Chen, F. 2001. The tectonics of the Strandja Massif: late Variscan and mid Mesozoic deformation and metamorphism in the northern Aegean. International Journal of Earth Sciences 90, 217-33.

OKay, A. I., Sunal, G., Sherlock, S., Altiner, D., Tüysüz, O., Kylander-Clark, A. R. C. \& AygüL, M. 2013. Early Cretaceous sedimentation and orogeny on the southern active margin of Eurasia: Central Pontides, Turkey. Tectonics 32, 1247-71

OKAY, A. I. \& TÜYSÜZ, O. 1999. Tethyan sutures of northern Turkey. In The Mediterranean Basins: Tertiary Extension within the Alpine Orogen (eds B. Durand, L. Jolivet, F. Horvath \& M. Seranne), pp. 475-515. Geological Society of London, Special Publication no. 156.

OKaY, A. I., TÜYsüz, O., SATIR, M., ÖZKan-Altiner, S., Altiner, D., Sherlock, S. \& EREN, R. H. 2006. Cretaceous and Triassic subduction-accretion, highpressure-low-temperature metamorphism, and continental growth in the Central Pontides, Turkey. Geological Society of America Bulletin 118 (9/10), 1247-69.

OKaY, A. I. \& WhitneY, D. L. 2010. Blueschists, eclogites, ophiolites and suture zones in northwest Turkey: a review and a field excursion guide. Ofioliti 35, 131-72.

Parlak, O., Yilmaz, H. \& BoztuĞ, D. 2006. Geochemistry and tectonic setting of the metamorphic sole rocks and isolated dykes from the Divriği ophiolite (Sivas, Turkey): evidence for melt generation within an asthenospheric window prior to ophiolite emplacement. Turkish Journal of Earth Sciences 15, 25-45.

Pourteau, A., Candan, O. \& Oberhänsli, R. 2010 High-pressure metasediments in central Turkey: constraints on the Neotethyan closure history. Tectonics $\mathbf{2 9}$, TC5004. doi: 10.1029/2009TC002650.

Pourteau, A., Oberhänsli, R., Candan, O., Barrier, E. \& VRIELYNCK, B. 2015. Neotethyan closure history of western Anatolia: a geodynamic discussion. International Journal of Earth Sciences 105, 203-24.

Pourteau, A., Sudo, M., Candan, O., Lanari, P., Vidal, O. \& OвERHÄNSLI, R. 2013. Neotethys closure history of Anatolia: insights from ${ }^{40} \mathrm{Ar}-{ }^{39} \mathrm{Ar}$ geochronology and $P-T$ estimation in high-pressure metasedimentary rocks. Journal of Metamorphic Geology 31, 585-606.

Régnier, J. L., Ring, U., Passchier, C. W., Gessner, K. \& GüNGÖR, T. 2003. Contrasting metamorphic evolution of metasedimentary rocks from the Cine and Selimiye nappes in the Anatolide belt, western Turkey. Journal of Metamorphic Geology 21, 699-721.

Rieder, M., Cavazzini, G., D'yakonov, Yu. S., FrankKamenetskiI, V. A., Gottardi, G., Guggenheim, S., Koval, P. V., Mueller, G., Neiva, A. M. R., Radoslovich, E. W., Robert, J. L., SASSI, F. P., TAKedA, H., Weiss, Z. \& WonES, D. R. 1998. Nomen- 
clature of the micas. The Canadian Mineralogist 36. 905-12.

Rimmelé, G., Oberhansli, R., Goffe, B., Jolivet, L., Candan, O. \& Çetinkaplan, M. 2003. First evidence of high-pressure metamorphism in the "Cover Series" of the southern Menderes Massif. Tectonic and metamorphic implications for the evolution of SW Turkey. Lithos 71, 19-46.

Ring, U., Will, T., Glodny, J., Kumerics, C., Gessner, K., Thomson, S. N., Güngör, T., Monié, P., OKrusch, M. \& DRÜPPEL, K. 2007. Early exhumation of high-pressure rocks in extrusion wedges: the Cycladic blueschist unit in the eastern Aegean, Greece and Turkey. Tectonics 26, TC2001. doi: 10.1029/2005TC001872.

Robertson, A., Parlak, O., Ustä̈mer, T., Tasli, K., InAN, N., Dumitrica, P. \& KaraoĞLan, F. 2014. Subduction, ophiolite genesis and collision history of Tethys adjacent to the Eurasian continental margin: new evidence from the Eastern Pontides. Turkey. Geodinamica Acta 26, 230-93.

Robertson, A. H. F., Ustä̈mer, T., Pickett, E., Collins, A., Andrew, T. \& Dixon, J. E. 2004. Testing models of Late Palaeozoic-Early Mesozoic orogeny in Western Turkey: support for an evolving open-Tethys model. Journal of the Geological Society, London 161, 501-11.

Rock, N. M. S. \& LeAKE, B. E. 1984. The International Mineralogical Association amphibole nomenclature scheme: computerization and its consequences. Mineralogical Magazine 48, 211-27.

RojaY, B. 1995. Post-Triassic evolution of Central Pontides: evidence from Amasya region, Northern Anatolia. Geologica Romana 31, 329-50.

RoJAY, B. 2013. Tectonic evolution of the Cretaceous Ankara Ophiolitic Melange during the Late Cretaceous to preMiocene interval in Central Anatolia, Turkey. Journal of Geodynamics 65, 66-81.

ŞENGör, A. M. C. 1984. The Cimmeride Orogenic System and the Tectonics of Eurasia. Geological Society of America, Special Paper no. 195, 82 pp.

ŞENGöR, A. M. Ç. \& YILMAZ, Y. 1981. Tethyan evolution of Turkey: a plate tectonic approach. Tectonophysics $\mathbf{7 5}$, 181-241.
Şengör, A. M. C., TÜysüz, O., Imren, C., Sakinç, M., EyidoĞAn, H., Görür, N. \& Rangin, C. 2005. The North Anatolian Fault: a new look. Annual Review of Earth and Planetary Sciences 33, 37-112.

Sherlock, S., Kelley, S., Inger, S., Harris, N. \& OKay, A. I. 1999. 40Ar-39Ar and $\mathrm{Rb}-\mathrm{Sr}$ geochronology of high-pressure metamorphism and exhumation history of the Tavsanli Zone, NW Turkey. Contributions to Mineralogy and Petrology 137, 46-58.

Stampfli, G., Marcoux, J. \& Baud, A. 1991. Tethyan margins in space and time. In Palaeogeography and $\mathrm{Pa}$ laeoceanography of Tethys (eds J. E. T. Channell, E. L. Winterer \& L. F. Jansa). Palaeogeography, Palaeoclimatology, Palaeoecology 87, 373-410.

Topuz, G., GöçMengil, G., Rolland, Y., Çelik, Ö. F., ZACK, T. \& SchmitT, A. K. 2013. Jurassic accretionary complex and ophiolite from northeast Turkey: no evidence for the Cimmerian continental ribbon. Geology 41, 255-8.

Ustä̈mer, T. \& Robertson, A. H. F. 1997. Tectonicsedimentary evolution of the north Tethyan margin in the Central Pontides of northern Turkey. In Regional and Petroleum Geology of the Black Sea and Surrounding Region (ed. A. G. Robinson), pp. 255-90. American Association of Petroleum Geologists Memoirs no. 68 .

Ustä̈mer, T. \& Robertson, A. H. F. 1999. Geochemical evidence used to test alternative plate tectonic models for pre-Upper Jurassic (Palaeotethyan) units in the Central Pontides, N Turkey. Geological Journal 34, 25 53.

Ustä̈mer, T. \& Robertson, A. H. F. 2010. Late PaleozoicEarly Cenozoic tectonic development of the eastern Pontides (Artvin area), Turkey: stages of closure of Tethys along the southern margin of Eurasia. In Sedimentary Basin Tectonics from the Black Sea and Caucasus to the Arabian Platform (eds M. Sosson, N. Kaymakçı, R. A. Stephenson, F. Bergerat \& V. Starostenko), pp. 281-327. Geological Society of London, Special Publication no. 340.

ZANE, A. \& WeIss, Z. 1998. A procedure for classifying rock-forming chlorites based on microprobe data. Rendiconti Lincei 9, 51-6. 